\title{
Impact of Cardamom Cultivation on the Composition and Dynamics of Soil Seed Banks in a Conservation Forest in Sri Lanka: Implications for Conservation
}

\author{
Balram Dhakal1,2 \\ ${ }^{1}$ Communities and Nature International, Peterborough, UK \\ ${ }^{2}$ University of Aberdeen, Aberdeen, UK \\ Email: dhakalbalram@gmail.com
}

How to cite this paper: Dhakal, B. (2017). Impact of Cardamom Cultivation on the Composition and Dynamics of Soil Seed Banks in a Conservation Forest in Sri Lanka: Implications for Conservation. Open Journal of Forestry, 7, 307-335. https://doi.org/10.4236/ojf.2017.73019

Received: January 5, 2017

Accepted: May 12, 2017

Published: May 15, 2017

Copyright $\odot 2017$ by author and Scientific Research Publishing Inc. This work is licensed under the Creative Commons Attribution International License (CC BY 4.0).

http://creativecommons.org/licenses/by/4.0/ (c) (i) Open Access

\begin{abstract}
Cultivation of cash crops, such as cardamom (Elettaria cardamomum) in the forest understorey is a common practice in many tropical forests. Over time, cultivation may change forest structure and species composition, leading to gradual degradation of biodiversity and ecosystem services. Effective conservation of these forests requires an enhanced understanding of the demographic processes such as soil seed bank that may greatly influence future forest composition. We examined how the soil seed bank structure and composition responds to cardamom cultivation in a high conservation value Sri Lankan montane rain forest. Soil samples from natural forest with abandoned cardamom plantations (CP) and adjacent natural forest (NF) patches without cardamom were collected in dry and wet seasons. Soil samples were spread out in trays in a shade house and germination was recorded weekly for 19 weeks. The density of seeds in the soil seed bank was much higher in CP than NF. While grasses and forbs contributed the highest number and percentage of seeds in soils of both forest types, their densities in the soil seed bank were 9 and 2 times greater in the CP than the NF, respectively. Seeds of the nonnative herbs Ageratina riparia and E. cardamomum were 4 and 20 times greater in the soil of CP, respectively. Seeds of light demanding tree species such as Macaranga indica were restricted to soils of CPs. Overstorey tree community of each forest type was poorly represented in their respective soil seed banks. The high density of seeds of pioneer trees and non-native herbs in the soil of $\mathrm{CPs}$, combined with higher light transmission to the ground floor may exacerbate competition for resources with the seedlings of late successional trees of high conservation value. To overcome this barrier and enhance conservation
\end{abstract}


value of the forest, restoration strategies may need to focus on transplanting seedlings of these species into forest with abandoned cardamom plantations.

\section{Keywords}

Cardamom Cultivation, Forest Restoration, Knuckles, Soil Seed Bank, Sri Lanka

\section{Introduction}

Agro-ecosystems are important elements of many tropical landscapes, as they contribute to local livelihoods and provide environmental services. As in other areas in the tropics where perennial crops have been integrated with forest trees (Bhagwat et al., 2008; Parthasarathy, 1999; Pascarella et al., 2000; Rivera et al., 2000; Rivera \& Aide, 1998), in parts of Asia many forests have been cultivated with the high-value spice crop cardamom (Elettaria cardamomum (L.) Maton) (Buckingham, 2004; Kumar et al., 1995; Reyes et al., 2006). Despite its socioeconomic benefits, the system of cardamom cultivation in tropical Asian forests has been criticised for being incompatible with conservation of forest resources (Ashton et al., 2001; Dhakal et al., 2012; Gunawardane, 2003). Cardamom cultivation and management involves the selective removal of canopy trees and regular maintenance by removal of competing plants in the forest understorey (Anon, 2002; Bandaratillake, 2005; Buckhingham, 2004; Kumar et al., 1995). This system of cultivation may hinder the capacity of forests to regenerate and undermine their conservation value (Ashton et al., 2001). Therefore, research on restoration techniques for high conservation value forests affected by repeated cardamom cultivation should be a high priority to conserve biodiversity and ecosystem services they support.

Restoration of forests following disturbance hinges on understanding the pathways by which plant species colonise the sites and the constraints on recruitment of late successional tree species. The soil seed bank represents an important source of propagules for regeneration of forests following agricultural use (Decocq et al., 2004; Pickett \& McDonnell, 1989; Quintana-Ascencio et al., 1996; Saulei \& Swaine, 1988; Swaine \& Hall, 1983; Thompson, 1992; Uhl et al., 1981). A comparison of soil seed banks between undisturbed and adjacent degraded forests may contribute to understanding the impacts of disturbance on the density and community structure of buried seeds, and the capacity of soil seed banks to contribute to forest recovery and/or inhibit tree regeneration. Although the soil seed bank is not likely to represent an important source of propagules for regeneration of late-successional trees (Tekle \& Bekele, 2000), it may contain a higher density of plant groups, such as pioneer trees, grasses, forbs and non-native species, which may impact future forest composition through competition with newly-emerged tree seedlings (Denslow et al., 2006). Thus this assessment contributes baseline knowledge for designing approaches to the restoration and management of disturbed forests (Butler \& Chazdon, 
1998; Lemenih \& Teketay, 2006; Martins \& Engel, 2007; Richter \& Stromberg, 2005; Wang et al., 2009). Several studies have documented a higher density of seeds, a higher proportion of early successional species and a greater species diversity in the seed banks of tropical forests disturbed by shifting cultivation or logging than in adjacent undisturbed forests (Alvarez-Aquino et al., 2005; Arevalo \& Fernandez-Palacios, 2000; Dalling \& Denslow, 1998; Leckie et al., 1999; Osumi \& Sakurai, 1997; Quintana-Ascencio et al., 1996; Saulei \& Swaine, 1988; Sousa et al. 2017). To our knowledge no studies have investigated the effects of cultivating a perennial crop in the understorey of a tropical forest on the density and composition of soil seed banks and their implications for forest regeneration and the future structure of the tree community.

The cultivation of cardamom in the understorey of lower montane rain forests (altitude between about $1000 \mathrm{~m}$ and $1400 \mathrm{~m}$ ) in Sri Lanka leads to a reduction in the density of trees $(\geq 5 \mathrm{~cm} \mathrm{DBH})$ and an increase in the relative abundance of light-demanding trees that form the forest canopy (Dhakal et al., 2012). These changes generate three predictions in terms of their impacts on the density and composition of the soil seed bank. First, the reduction in stem density may increase canopy openness and thereby light transmission to the forest floor $(\mathrm{Ku}-$ mar et al., 1995; Parthasarathy, 1999). An increase in light availability may stimulate the development of an herbaceous ground flora including non-native species comprising both grasses and forbs (Garwood, 1989; Leckie et al., 1999). Over time, these herbaceous species may come to dominate the soil seed bank of disturbed forests and contribute significantly to an increase in the overall density of buried seeds (Lemenih \& Teketay, 2006). An increase in the abundance of grasses, forbs and non-native species in soil seed banks would be important if these species impede regeneration of late-suecessional trees through inhibition of tree seedlings, especially once the canopy has been opened (Denslow et al., 2006; Guariguata \& Ostertag, 2001).

Secondly, the increase in relative abundance of light-demanding species in the tree canopy may be reflected in a parallel increase in the density of seeds of these species in the soil seed bank. In lower montane rain forest in the Knuckles Forest Reserve of Central Sri Lanka, the pioneer tree Macaranga indica Wight. has a substantially greater relative abundance in abandoned cardamom plantations than in adjacent undisturbed natural forest (Dhakal et al., 2012). As seeds of other Macaranga species, such as M. Peltata Roxb., and M. Heynei I. M. Johnst. are an important component of the soil seed banks of Asian tropical and subtropical forests (Chandrashekara \& Ramakrishanan, 1993; Lin et al., 2006; Metcalfe \& Turner, 1998), we predict that seeds of $M$. indica will be present in the soils that we sampled, but at much higher densities in the soils of abandoned cardamom plantations than adjacent natural forests.

Thirdly, it has been documented that when a landscape undergoes extensive change as a result of human activities, plant communities become more susceptible to invasion by non-native plant species (Hansen \& Clevenger, 2005). In 
some cases, these non-native species may increase in abundance in the soil seed banks of forests disturbed by human use (Conn et al., 1984; Lin et al., 2006; Moffatt et al., 2004; Peterson \& Carson, 1996). Hence, we test the prediction that forests disturbed by cardamom cultivation manifest a greater abundance and species richness of non-native species in the soil seed bank than in adjacent undisturbed natural forests.

The aim of this study was to determine how the composition and structure of the soil seed bank responds to the introduction of a cardamom crop in a high conservation value lower montane rain forest in Sri Lanka. This research underpins the development of strategies for restoration and conservation of forests containing abandoned cardamom plantations in the buffer zone of a globally significant World Heritage Site. Data on the ecological impacts of cultivating perennial cash crops beneath a closed tree canopy are scarce, despite the widespread occurrence of analogous agroforest-ecosystems involving crops such as coffee, cocoa and ginger (Bhagwat et al., 2008; Schroth \& da Mota, 2013). Specifically, by comparing the density and composition of soil seed banks in abandoned cardamom plantations to those in adjacent undisturbed forests, we tested the following predictions: 1) the density of seeds in the soil seed bank has increased in response to disturbance associated with cultivation in the abandoned cardamom plantation; 2) this difference is associated with a rise in the abundance of herbaceous plants in the seed bank of the disturbed forest; 3) seeds of light-demanding pioneer trees such as Macaranga species are present at a higher density in the soil of the abandoned cardamom plantation, reflecting their greater abundance in the above-ground tree community; and 4) seeds of nonnative species are present at a higher density in the soil of the abandoned cardamom plantation than in the soil of undisturbed forest.

\section{Materials and Methods}

\subsection{Study Site}

This study was undertaken in the Knuckles Forest Reserve (KFR, $7^{\circ} 21^{\prime} \mathrm{N}$ to $7^{\circ} 24^{\prime} \mathrm{N}, 80^{\circ} 45^{\prime} \mathrm{E}$ to $80^{\circ} 48^{\prime} \mathrm{E}$ ), which extends over 21,000 ha in the central highlands of Sri Lanka (Balasubramaniam, 1988; Bambaradeniya \& Ekanayake, 2003). The KFR contains a range of natural vegetation types reflecting steep gradients of altitude and climate, as well as patches of human-induced grassland, areas of shifting cultivation, and plantations of Pinus caribaea Morelet (Bambaradeniya \& Ekanayake, 2003). The study site was located in lower montane rain forest at 1032 - $1274 \mathrm{~m}$ close to the settlement of Riverston $\left(7^{\circ} 31^{\prime} \mathrm{N}, 80^{\circ} 44^{\prime} \mathrm{E}\right)$ in the north-eastern part of KFR (Figure 1). The mean monthly rainfall at the study site ranges from $93 \mathrm{~mm}$ (May) to $673 \mathrm{~mm}$ (January) (MSP, 2009). The mean annual temperature ranges from $18^{\circ} \mathrm{C}$ to $26^{\circ} \mathrm{C}$ (Gunaratne, 2007). The dominant tree species forming the canopy in the cardamom plantations are Macaranga indica, Neolitsea cassia (L.) Kosterm., Elaeocarpus glandulifer (Hook. Ex Wright) Mast., Turpinia malabarica Gamble, and Symplocos cochinchinensis (Lor.) 


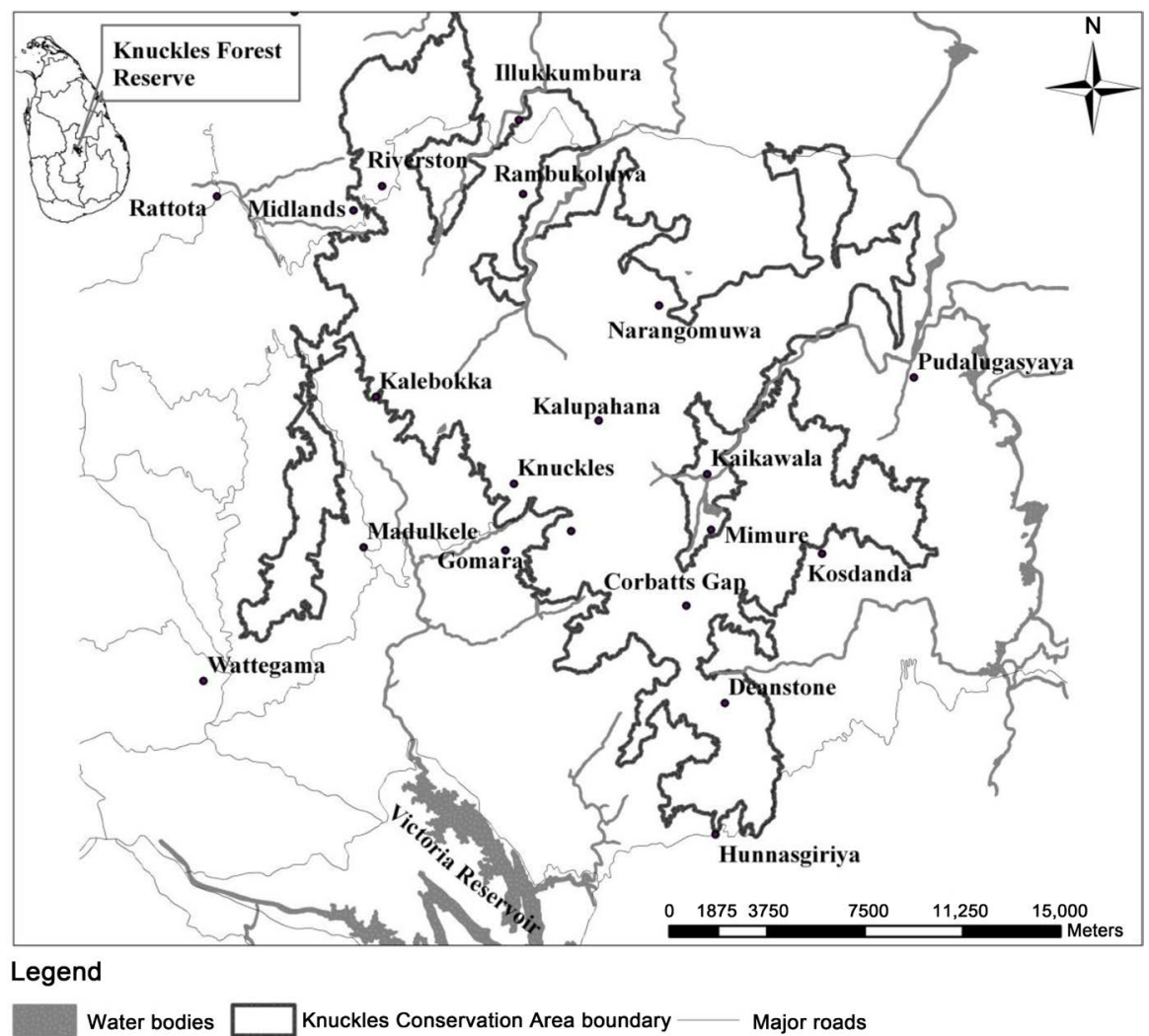

Figure 1. Map of Knuckles Forest Reserve, Sri Lanka, showing different areas and land use types.

Moore var laurina, and in the natural forests the most common canopy tree species are Calophyllum trapezifolium Thwaites., Syzygium operculatum (Roxb.) Nied., Schefflera sp., and Psychotria thwaitesii Hook. f. (Dhakal et al., 2012).

Cardamom is a perennial spice crop originating in Asia and parts of Africa (Buckhingham, 2004). It is a perennial herb with pseudo stems (technically leaves) extending to $2-3 \mathrm{~m}$ in height from a fleshy branched rhizome. Cardamom displays an optimum productivity when grown in about $50 \%$ shade and establishes well under the canopy of tropical montane forests. Cardamom gains reproductive maturity three years after planting, and has an economic life of $10-15$ years (Nybe et al., 2007). Pods or seed capsules grow low to the ground and contain the black, green or white seeds. The seed capsules are highly aromatic, which explains their use as a spice and in traditional medicine as a tonic or infusion.

Official records suggest that cardamom has been planted into about 3000 ha of natural montane forests within the KFR (Gurusinghe, 1988; IUCN, 1994). However, this figure is likely to be an underestimate of the total area under cardamom cultivation because we observed very few patches of natural montane forest that lacked cardamom in the understorey during three years of research. Cardamom cultivation in the forest started more than a century ago (Gurusinghe, 1988) and the plantations were managed continuously until the Knuckles Conservation Area (KCA) was established in 1985. At that time, formal management of the cardamom plantations ceased because cultivation within the 
KCA was prohibited (Anon, 2000; IUCN, 1994). By that time cardamom had been planted into most of the suitable forest, and remaining patches of natural forest without cardamom were small and widely scattered, including some areas where there was conflict over land ownership. The average ( \pm SE) density of cardamom plants in the abandoned cardamom plantations at the time of this study was $7525( \pm 973) \mathrm{ha}^{-1}$.

\subsection{Plot Selection and Sampling of the Soil Seed Bank}

Plots $(10 \mathrm{~m} \times 10 \mathrm{~m})$ established for tree regeneration studies (Dhakal, 2011) were used for locating samples in this study. Forty-eight plots were sampled in cardamom plantation (CP), derived from eight blocks of each six contiguous plots, and eight non-contiguous plots were sampled in natural forest without cardamom (NF). The maximum distances between blocks and between CP and NF plots were $1.4 \mathrm{~km}$ and $1.8 \mathrm{~km}$, respectively.

Two soil samples $(10 \mathrm{~cm} \times 10 \mathrm{~cm} \times 5 \mathrm{~cm}$ deep) were collected from locations selected at random within $50 \mathrm{~cm}$ of the edge of two opposite sides of each plot and mixed thoroughly to make a composite sample of $20 \mathrm{~cm} \times 10 \mathrm{~cm} \times 5 \mathrm{~cm}$. This procedure yielded 48 samples from CP and eight samples from NF. Sampling was repeated on two occasions: 15 August 2008 (end of dry season) and 26 February 2009 (end of wet season). On the day of collection, soil samples were spread out in polythene trays to a depth of $5 \mathrm{~mm}$ on the surface of sterilised sand (4 cm deep) in a shade house at $550 \mathrm{~m}$ a.s.l. Two trays $40 \mathrm{~cm} \times 25 \mathrm{~cm} \times 5 \mathrm{~cm}$ per sample were used to accommodate each sample and the trays were placed randomly in the shade house. The sand was steam-sterilised uniformly to kill contaminating seeds. For each set of samples, eight additional heat-sterilized soil samples were also spread over sand in trays and monitored to determine the extent of contamination by seeds blown or carried into the shade house. Four seedlings representing three morphotypes (individuals with similar morphology, but in some cases and unknown species identity)—one Cyperus, one Biophytum and one unknown, and three seedlings of three morphotypes-one Hedyotis and two unknown emerged from these control samples during the study of dry and wet season seed banks, respectively. As these numbers represented a very small percentage of total seedling emergence $(<0.08 \%)$, contamination was ignored during data analysis.

All trays were watered regularly and germination was recorded weekly for 19 weeks, which represented approximately 2 weeks since germination had ceased in all cases. Emergents were counted and marked using toothpicks, and categorised into different morphotypes. The trays were randomly relocated twice a month to reduce the difference in environmental conditions for replicate trays during the study period. After 16 or 17 weeks, the soil was turned over to promote the germination of deeply buried seeds. Herbarium specimens of each morphotype were prepared and identified by comparison with specimens in the National Herbarium, Peradeniya (PDA). 


\subsection{Measurement of Canopy Openness and Standing Vegetation}

Canopy openness in the forest was estimated from hemispherical photographs (Nikon Coolpix 995 camera body with a FC-E8 0.21x Nikon fisheye lens, Nikon Corporation, Japan) taken at the centre of each $10 \mathrm{~m} \times 10 \mathrm{~m}$ plot between 6 a.m. and 8 a.m. to avoid direct sunlight in the field of view. The camera with hemispherical lens was placed in a self-levelling camera mount at a height of $1.4 \mathrm{~m}$ above ground level, and oriented to true north while taking photographs. The hemispherical photographs were converted to black and white images by using Adobe Photoshop (2008 Adobe Systems Incorporated, USA), and percentage canopy openness estimated by using the software WINPHOT 5.0 (ter Steege,, 1996).

To compare the species composition of the seed bank with that of the standing tree community in each plot, all trees $\geq 5 \mathrm{~cm}$ DBH in each $10 \mathrm{~m} \times 10 \mathrm{~m}$ plot were recorded and identified following the same procedure used to identify the species in the soil seed bank (Dhakal, 2011). Although the soil samples were collected up to $50 \mathrm{~cm}$ outside opposite edges of these plots, seed dispersal limitation would not be sufficient at this scale to represent a severe constraint to comparison of below- and above-ground plant communities.

\subsection{Micro-Climatic Measurements}

Sensors attached to a Skye Data Hog 2 (Model SDL 5490, Skye Instruments Ltd, UK) were used to measure photosynthetically active radiation (PAR; SKP 215), air temperature (SKTS 200U/I), relative humidity (SKH 2040/I), and soil temperature (SKTS 200/I) in the shade house and in plots with abandoned cardamom and in natural forests during April-June 2009 to provide contextual information.

The sensors inside the shade house were located adjacent to the germination trays whereas in the cardamom plantations and natural forests they were placed in the plots where trees were censused. The soil temperature sensor inside the shade house was buried to a depth of ca. $4 \mathrm{~cm}$, in one of the seed trays. Photosynthetically active radiation and air temperature were recorded $10 \mathrm{~cm}$ above ground, and soil temperature in the forests was recorded at $4 \mathrm{~cm}$ below ground. The air temperature sensor was covered by a white plastic cup to avoid direct heating by solar radiation. Data from all sensors were collected at 10 -second intervals and averaged over 30 minutes for five consecutive days in each location.

The mean $( \pm \mathrm{SE})$ values inside the shade house, in an abandoned cardamom plantation and in a natural forest, respectively, were as follows: PAR, $5.13 \pm 0.33$, $11.2 \pm 1.99$, and $8.30 \pm 1.81 \mathrm{~mol} \mathrm{~m}^{-2} \mathrm{day}^{-1}$; soil temperature, $24.4^{\circ} \mathrm{C} \pm 0.05^{\circ} \mathrm{C}$, $20.9^{\circ} \mathrm{C} \pm 0.03^{\circ} \mathrm{C}$, and $20.5^{\circ} \mathrm{C} \pm 0.06^{\circ} \mathrm{C}$; air temperature, $23.7^{\circ} \mathrm{C} \pm 0.09^{\circ} \mathrm{C}, 20.6^{\circ} \mathrm{C} \pm$ 0.10 , and $20.8^{\circ} \mathrm{C} \pm 0.13^{\circ} \mathrm{C}$; and relative humidity, $80.5 \% \pm 0.45 \%, 91.5 \% \pm 0.31 \%$, and $92.7 \% \pm 0.10 \%$. Statistical analysis of these data was not possible because the measurements were not made simultaneously and spatial variance within sites was not determined, but they suggest that the seed trays may have been exposed to lower PAR and relative humidity, and higher soil and air temperature than forest floor environments that were sampled for soil seed banks. However, the conditions 
in the shade house are unlikely to have been limiting for seed germination based on published information for tropical plants (Baskin \& Baskin 1998), and we do not consider that these differences therefore bias our conclusions.

\subsection{Data Analysis}

The mean $( \pm \mathrm{SE})$ density of emergents per square metre was calculated for cardamom plantations (CP) and natural forests (NF) for both dry and wet seasons and for the pooled data from both seasons. To account for the nesting of plots within blocks of the CP, generalised linear mixed models (GLMM) implemented using the glmmPQL function in the MASS package of R v. 1.11.1 (R Core Development Team, 2010) were fitted to counts of seeds emerging from the soil seed bank. This function fits a generalised linear mixed model with multivariate random effects, using penalised quasi-likelihood (Zuur et al., 2009). Models fitting counts of seeds included a log link function and tested the contrasts in seed density in the soil seed bank between abandoned cardamom plantations and natural forests and between wet and dry seasons with count of seeds emerging from the soil seed bank as a fixed effect, and the plots (including nested within block) as random effects. In all cases the full model including all main effects and their interactions was fitted first and then simplified by sequential removal of the non-significant terms. Graphical methods were used to assess how well the models fit the data. The mean density per sample of non-native species in the soil seed banks of CP and NF during dry and wet seasons and in the data pooled across both seasons were analysed by using analogous models. The relative abundance of non-native species and the counts of seedling emergents in different life-form categories were compared between $\mathrm{CP}$ and NF for each season, and between seasons for data pooled across both forest types, using Chi-square tests.

Species richness of seeds in the seed banks of each forest type for dry and wet seasons, and in the pooled data, were estimated using EstimateS 7.5.2 (Colwell, 2006). Species accumulation curves were obtained by plotting cumulative species number against the cumulative number of individuals (individual-species curves) and comparisons of species richness were made for a standard sample of 400 emergents, which is the maximum number obtained for the smaller of the two samples. Fisher's alpha diversity index (Williams, 1947) was used for estimation of species diversity because it is relatively insensitive to sample size, and to the abundance of the most common species (Dalling \& Denslow, 1998). Values of Fisher's alpha for buried seeds were compared between CP and NF using analogous GLMM models. The total number of species per sample was compared between CP and NF for dry and wet seasons and for the pooled data across both seasons using the GLMM models with values of alpha diversity as fixed effects and the plots as random effects. The species evenness (equitability) was calculated using the values of Simpson's index estimated using Estimate $S$ and the species richness was compared between CP and NF using GLMM models with evenness as fixed factor and plots as fixed effects. 
We described the patterns of community composition in soil seed banks using non-metric multidimensional scaling (NMS) in PC-ORD (McCune \& Grace, 2002). The NMS ordinations were conducted using the Sorensen distance measure with 50 runs of real data and 50 runs of randomised data to generate a Monte Carlo test of significance (McCune \& Grace, 2002). The final stress of the ordination and coefficients of determination $\left(\mathrm{R}^{2}\right)$ are reported for each ordination axis as a proportion of the variation explained. A secondary matrix comprising site environmental variables (elevation and canopy openness) was overlaid on the NMS ordinations to aid interpretation of the distribution of samples and species. The strength and direction of the association of each environmental variable with variation in tree species composition are indicated by a vector in ordination space such that the length of the vector represents the rate of change in the weighted average as inferred from the biplot, and indicates how much the species distributions and sites differ along that environmental variable. The most important variables are those with the longest vector. In order to reduce the "noise" (McCune \& Grace, 2002) from infrequent species, species that were observed only once or twice were excluded from the NMS analysis. The data used in the secondary matrix were relativised (by general relativisation) since canopy openness was expressed on a percentage scale (McCune \& Grace, 2002). In order to analyse the patterns in soil seed bank across seasons and forest types, the data were pooled across seasons in CP and NF prior to the NMS analysis.

The differences in species composition of seed banks between $\mathrm{CP}$ and NF were also examined separately for dry and wet seasons and for data pooled across both seasons, using the multi-response permutation procedure (MRPP) (McCune \& Grace, 2002), which derives a test statistic, $\mathrm{T}$, and a $P$ value from a non-parametric multivariate test of differences among a priori groups. A more negative value for $\mathrm{T}$ indicates a stronger separation between groups (Elliott \& Swank, 2008). The Sørenson (Bray-Curtis) index was used as a distance measure for the MRPP analysis.

A comparison of the species composition of the seed bank with that of the tree $(\geq 5 \mathrm{~cm} \mathrm{DBH})$ community (standing vegetation) was conducted using Sørenson's similarity index for presence and absence data $(\mathrm{Cs})$ :

$$
\text { Cs }=2 j /(a+b)
$$

where $j$ is the number of species common to both the seed bank and tree communities, $a$ is the number of species in the seed bank, and $b$ is the number of species in the tree community (Dalling \& Denslow, 1998). The proportion of overstorey species that were represented in soil seed banks in each forest type was calculated and analysed by using Chi-square tests.

\section{Results}

\subsection{Density of Seeds in the Soil}

The density of seeds was significantly higher in the soil of the abandoned cardamom plantation than the natural forest (Table 1; Figure 2). A similar pattern 
Table 1. Mean values $( \pm \mathrm{SE})$ of species richness per sample, diversity and evenness and their statistical significance in the soil seed banks of cardamom plantation (CP) and natural forest (NF) during dry and wet seasons, and in data pooled across both seasons. The statistical significance is evaluated using $\mathrm{P}$ value, considering value $<0.05$ as significant. In order to avoid pseudo-replication, the GLMM models were used while analysing the data. The estimated numbers of species per sample of 400 seeds (with $95 \% \mathrm{CI}$ in parentheses) and the values of Sørensen's similarity index are also given.

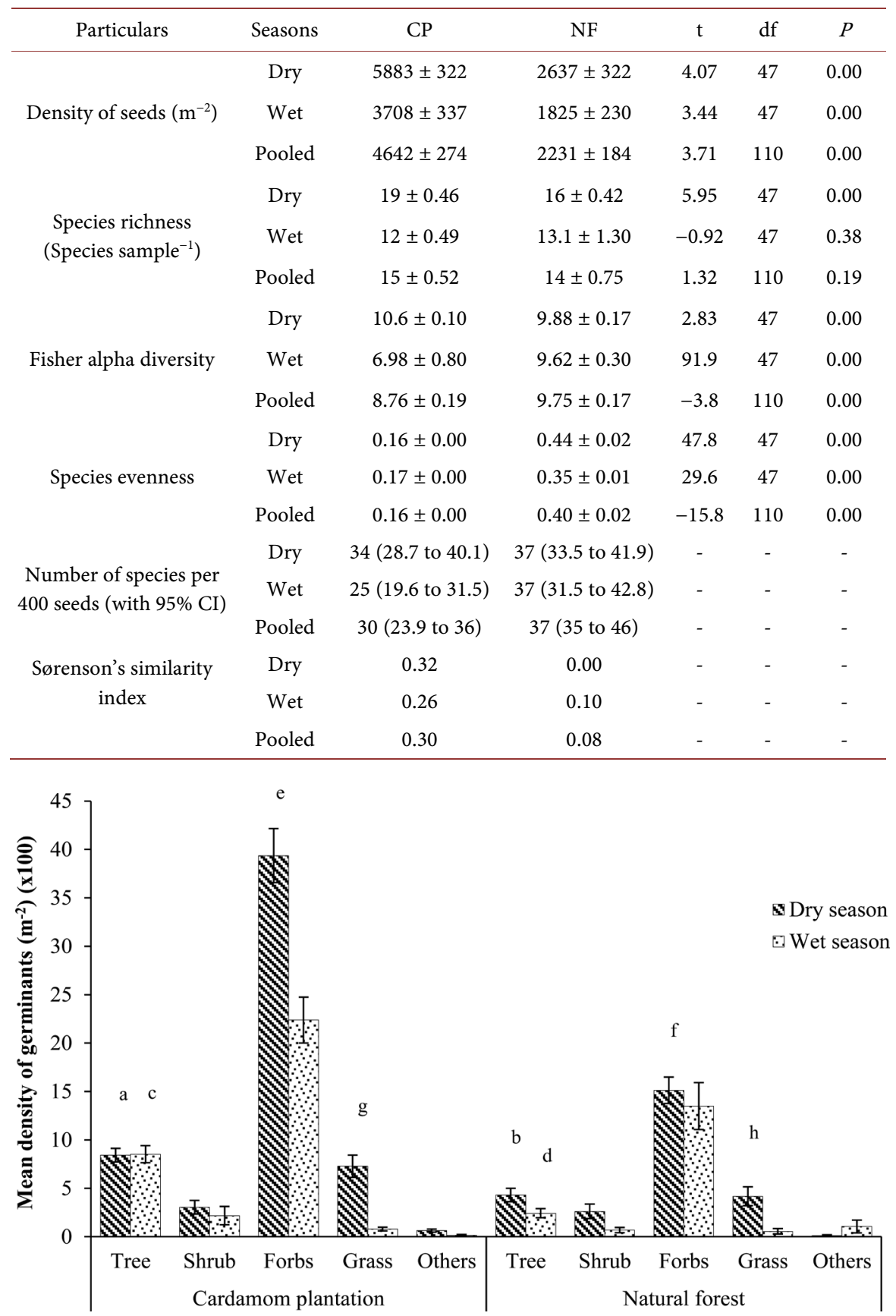

Figure 2. The density of germinants of trees, shrubs, forbs, grasses and others (unknowns, climbers and ferns) that emerged from soil taken from cardamom plantation (CP) and natural forest (NF) during dry and wet seasons. Different letters for life forms signify differences in densities between cardamom plantation and natural forest in two seasons at $P \leq 0.05$. The data were analysed using GLMM. 
was observed in the dry season and the wet season in CP and NF, respectively (Table 1). The overall seed density was higher $(\mathrm{t}=-4.93, \mathrm{df}=110, P<0.001)$ in the dry season $\left(5420 \pm 317 \mathrm{~m}^{-2}\right)$ than in the wet season $\left(3175 \pm 299 \mathrm{~m}^{-2}\right.$ ) (Figure $2)$. The interaction between forest types and season on density of seeds in the soil was not significant $(\mathrm{t}=0.49, \mathrm{df}=108, P>0.05)$.

\subsection{Life Form Distribution}

Grasses represented a greater proportion of buried seeds in the $\mathrm{CP}$ than in the $\mathrm{NF}$, in both the dry ( $22 \%$ vs. $18 \%$ respectively) and wet ( $11 \%$ vs. $5 \%)$ seasons (Figure 3). Forbs contributed the highest number and percentage of emergents in both forest types in both seasons (Figure 3). The proportion of tree seeds in the soil seed bank was higher in CP (25\%) than in NF (13\%) in the wet season, but it was lower in CP (14\%) than in NF (16\%) in the dry season (Figure 3). The proportional representation of different life-forms in the soil seed bank differed between dry and wet seasons in both $\mathrm{CP}(\mathrm{t}=6.18, \mathrm{df}=94, P<0.001)$ and NF $(\mathrm{t}$ $=4.10, \mathrm{df}=14, P<0.001)$, and between $\mathrm{CP}$ and NF for the combined data-set across both seasons (Figure 3; $\mathrm{t}=5.35, \mathrm{df}=110, P<0.001$ ).

\subsection{Composition and Richness of the Soil Seed Bank}

Emergents from the 48 soil samples taken from the CP represented 72 species in 30 families, whereas in the eight samples collected in the NF there were only 49 species in 24 families (Table A1; supplementary data). The season-wise counts were different: in the $\mathrm{CP}$ the respective counts in the dry/wet seasons were, 66/44 species in 30/21 families; in the NF they were 36/34 species in 20/20 families, which highlights a greater seasonal variation in the number of taxa in soils taken from the CP (Table A1).

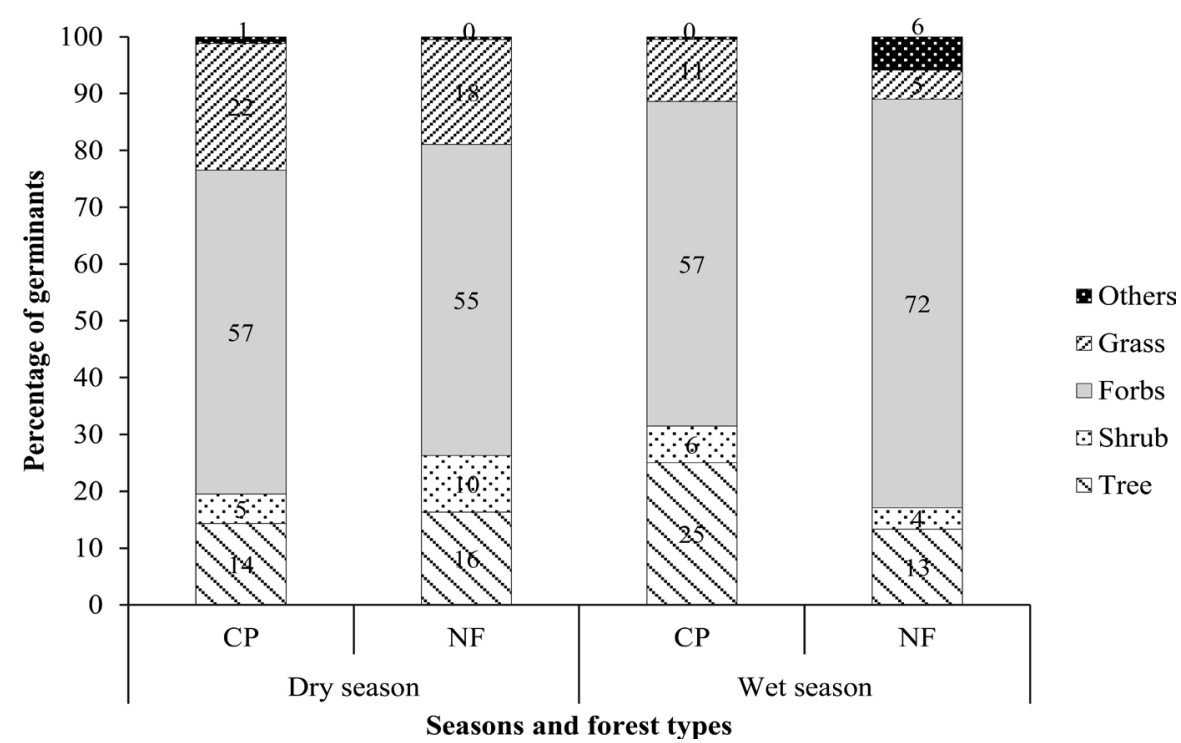

Figure 3. The percentages of trees, shrubs, forbs, grasses and others (unknowns, climber and fern species) in the soil seed banks of cardamom plantations (CP) and natural forests (NF) during dry and wet seasons. 
(a)

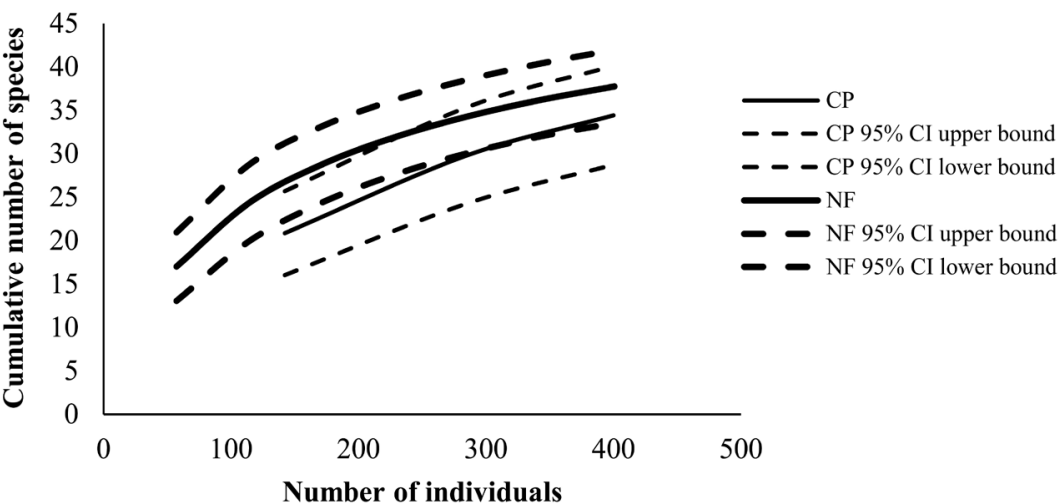

(b)
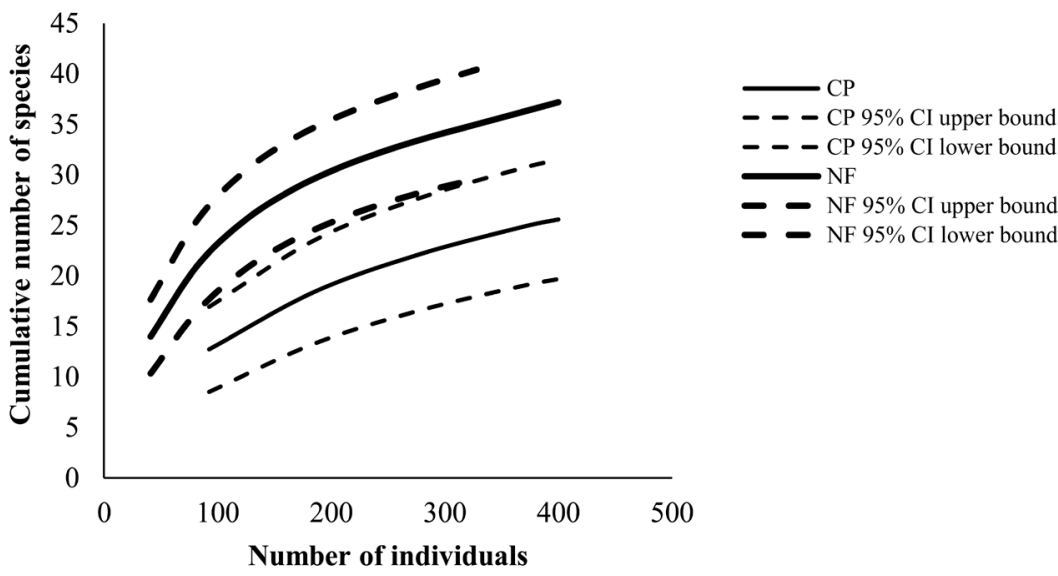

(c)

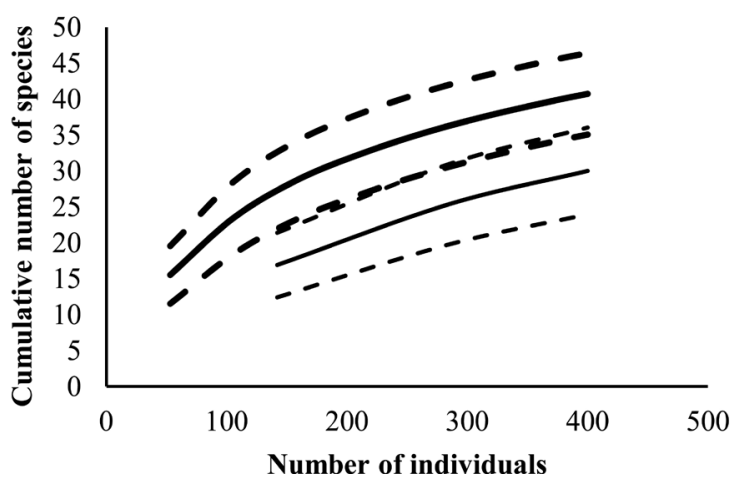

$\longrightarrow \mathrm{CP}$

- - - CP $95 \% \mathrm{CI}$ upper bound

- - - CP 95\% CI lower bound

NF

- NF $95 \%$ CI upper bound

- NF $95 \%$ Cl lower bound

Figure 4. Species accumulation curves against cumulative number of individual sampled for emergents from the soil seed banks of cardamom plantations and natural forests for dry (a) and wet (b) seasons, and pooled data from both seasons (c). Mean species richness was estimated using the computer program EstimateS 8.0 (Colwell, 2006).

Species richness per sample of the soil seed bank was higher in CP than in NF in the dry season, but not in the wet season. The pooled data across both seasons did not show any difference in species richness of the seed banks between the two forest types (Table 1). The rarefaction curves also suggest that species richness for a sample of 400 emergents was not different between CP and NF, either in the dry or the wet season (Figure 4(a), Figure 4(b)), or in the data pooled across both seasons (Figure 4(c)). Mean values of Fisher's alpha diversity in the $\mathrm{CP}$ in the dry season were higher and in the wet season lower than in the NF 
(Table 1). For the pooled data, the mean values of Fisher's alpha were lower in CP than in NF. The mean values of species evenness (equitability) of the soil seed bank were higher in the NF than in the CP in both dry and wet seasons and in the pooled data (Table 1 ).

In the soil seed bank of the CP, the most abundant species was Hedyotis nitida Wright and Arn. (Rubiaceae), which represented about $20 \%$ of all germinants (Table A1). In contrast, the most abundant species in the soil seed bank of NF was Oldenlandia corymbosa Linn. (Rubiaceae) which represented about $10 \%$ of all germinants (Table A1). The light-demanding species Macaranga indica, $M$. peltata and Symplocus cochinchinensis emerged only in soils taken from the CP. Macaranga indica represented $0.4 \%$ and $1.9 \%$ of all germinants in the dry and wet seasons, respectively.

The non-metric multidimensional scaling (NMS) ordination recommended three dimensions for the final solution. In the combined NMS analysis (data sets from both CP and NF sampled in two seasons), the final stress for the three dimensional solution was 18.9, which is acceptable for a reliable solution (McCune \& Grace, 2002). The proportions of variance explained were 31\% for Axis 1, 26\% for Axis 2, and $19 \%$ for Axis 3 (cumulative $\mathrm{R}^{2}$ of $76 \%$ for the first three ordination axes, Table 2). The two-dimensional plot representing the first two axes suggested that the samples were clustered in the ordination space, according to whether the samples were taken from $\mathrm{CP}$ or NF and whether sampling was conducted in the wet or dry season (Figure 5; Table 2). There was relatively little overlap among these four clusters, which suggests that the species composition of samples from each forest type and season was distinct. Samples from CP tended to have lower values along Axis 1 than those from NF in both seasons, which reflects a negative association between Axis 1 and canopy openness of the plot where the samples originated. Samples taken in the wet season tended to have higher values along Axis 2 than dry season samples for both forest types (Figure 5).

The light-demanding species M. indica, Acronychia pedunculata (L.) Miq., and $S$. cochinchinensis had relatively low values along Axis 1, which implies they

Table 2. Correlations of canopy openness and elevation with the first three axes of a non-metric multidimensional scaling ordination of seedlings emergence data from cardamom plantations and natural forests sampled in wet and dry seasons in the Knuckles Forest Reserve. Pearson's parametric ( $r$ ) and Kendall's non-parametric (tau) correlations with ordination axes $(n=112)$ are presented, with values of $r \geq 0.30$ highlighted in bold. Monte Carlo Test for stress in real data was $P<0.05$ for all axes shown.

\begin{tabular}{ccccccccc}
\hline \multirow{2}{*}{ Variables } & \multicolumn{2}{c}{ Axis 1 } & \multicolumn{2}{c}{ Axis 2 } & \multicolumn{2}{c}{ Axis 3 } \\
\cline { 2 - 9 } & $\mathbf{r}$ & tau & $\mathbf{r}$ & tau & r & tau \\
\hline Canopy openness & -0.32 & -0.17 & -0.09 & -0.05 & 0.26 & 0.15 \\
Elevation & 0.07 & 0.05 & 0.19 & 0.11 & -0.28 & -0.17 \\
Coefficients of determination & 0.31 & & 0.26 & & 0.19 & \\
Cumulative \% variance explained & 30 & & 57 & & 76 & \\
\hline
\end{tabular}




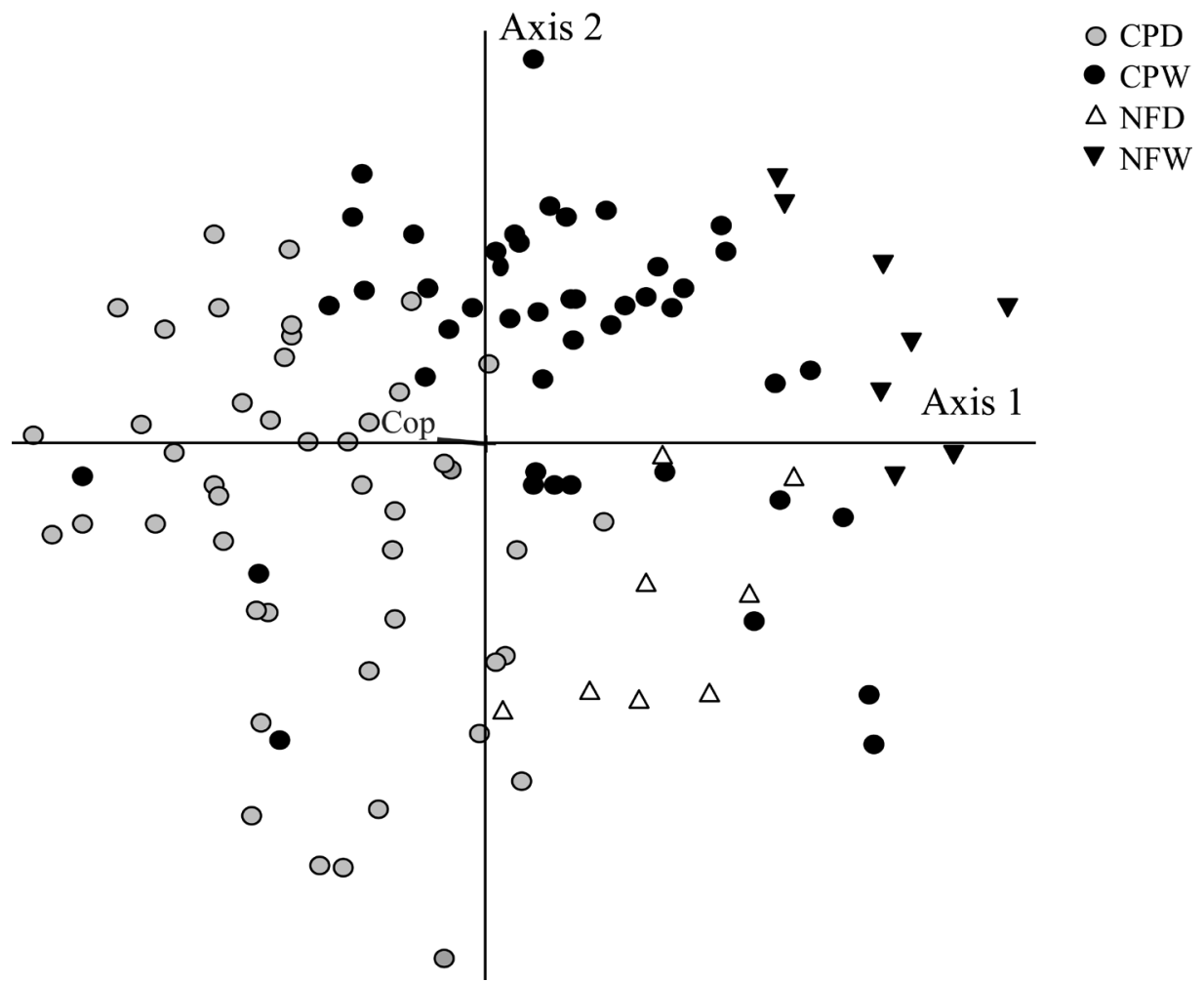

Figure 5. Non-metric multidimensional scaling ordination diagram of plot scores using combined emergence data for seed banks sampled from cardamom plantations (CPD and CPW) and natural forests (NFD and NFW) in dry (CPD and NFD) and wet seasons (CPW and NFW). The environmental variable associated with the distribution of plots was canopy openness (Cop).

were more strongly associated with samples from $\mathrm{CP}$ and plots with a higher canopy openness. Macaranga peltata was differentiated from $M$. indica by having a higher score along Axis 1 (Figure 6, Table A2).

The multi-response permutation procedure (MRPP) analyses suggested that there was marginally stronger separation between the soil seed bank communities of $\mathrm{CP}$ and NF in the dry season $(\mathrm{T}=-12.7, \mathrm{~A}=0.05, P<0.001)$ than in the wet season $(\mathrm{T}=-10.4, \mathrm{~A}=0.03, P<0.001)$, as a more negative value of $\mathrm{T}$ describes a stronger separation between groups. Analysis by MRPP for data pooled across seasons also indicated a strong separation in species composition of the soil seed banks of NF and $\mathrm{CP}(\mathrm{T}=-15.5, \mathrm{~A}=0.03, P<0.001)$.

\subsection{Affinity between Soil Seed Bank and the Standing Tree Community}

Only $23 \%$ of the tree species ( 7 out of 30 ) in the standing vegetation $\geq 5 \mathrm{~cm} \mathrm{DBH}$ in the CP (mean \pm SE species richness plot $^{-1}: 4.75 \pm 0.24$ ) were represented in the soil seed bank ( $4.35 \pm 0.19)$, and in NF only $9 \%$ of the tree species ( 1 out of 11) of the standing vegetation $\geq 5 \mathrm{~cm} \mathrm{DBH}(4.50 \pm 0.33)$ was represented in the seed bank $(3.00 \pm 0.42)\left(\chi^{2}=1.62, \mathrm{df}=2, P=0.44\right.$, Table A1, Table A3 and Table A4). Values of Sørenson's similarity index (Cs), comparing the species 


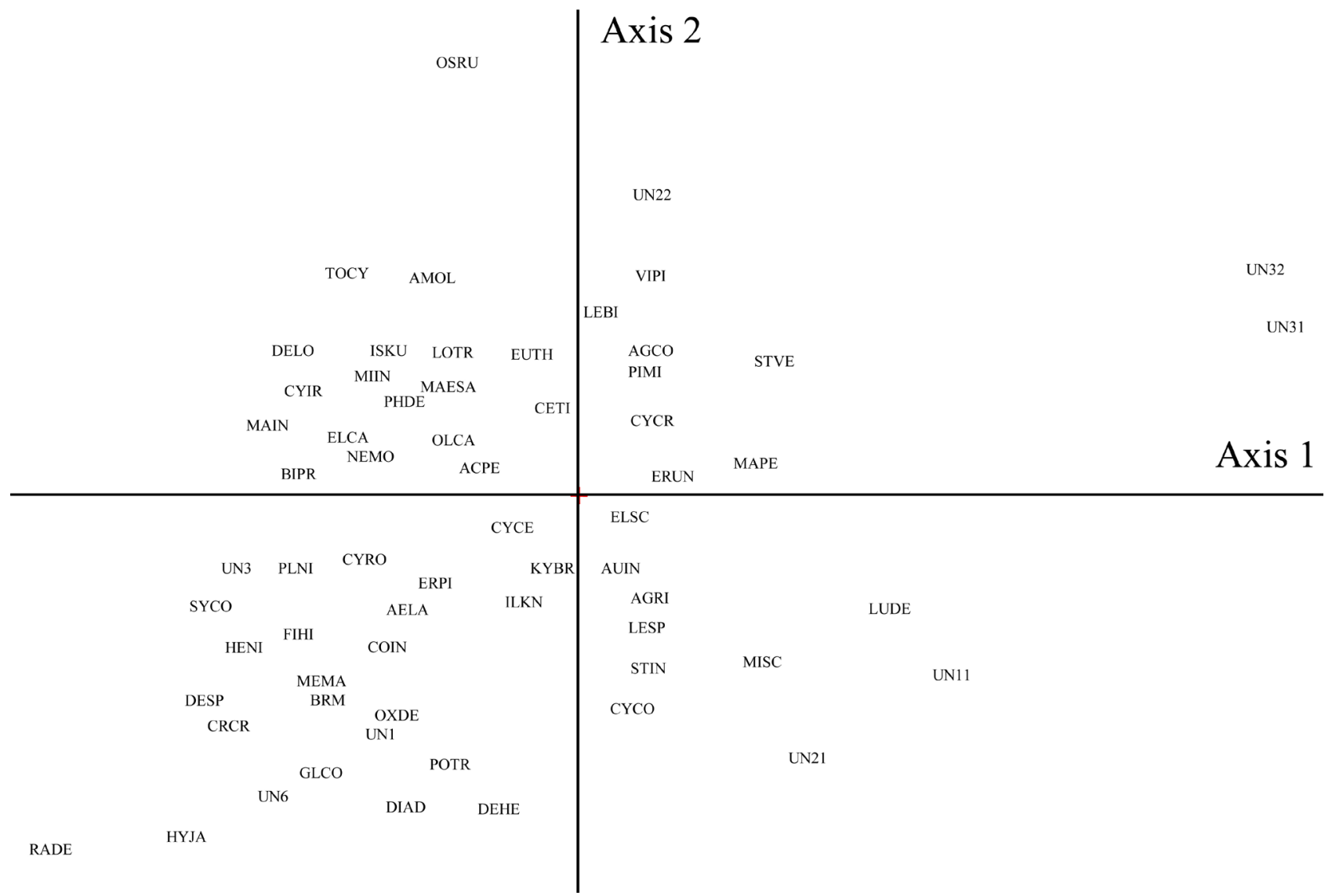

Species codes: ACPE = Acronychia pedunculata; AELA = Aerva lanata AGCO = Ageratum conyzoides, AGRI $=$ Ageratina riparia AMOL $=$ Amaranthus oleraceus, $\mathrm{AUIN}=$ Austroeupatorium inulifolium; $\mathrm{BIPR}=$ Biophytum proliferum; $\mathrm{BRMI}=$ Brachiaria miliformis, $\mathrm{CETI}=$ Celtis timorensis , COIN $=$ Commelina indhiscens, $\mathrm{CRCR}=$ Crassocephalum crepidioides, $\mathrm{CYCR}=$ Cyanotis cristata CYCE $=$ Cynotis ceylanica; $\mathrm{CYCO}$ = Cyperus compressus, $\mathrm{CYIR}=$ Cyperus iria; $\mathrm{CYRO}=$ Cyperus rotundus, $\mathrm{DELO}=$ Debregeasia longifolia , DEHE = Desmodium heterophyllum; DESP = Desmodium sp.; DIAD = Digitaria adscendens, ELSC = Elephantopus scaber, ELCA = Elettaria cardamomum; ERPI = Eragrostis pilosa; ERUN $=$ Eragrostis unioloides , EUTH $=$ Euphorbia thymifolia; FIHI $=$ Ficus hispida $;$ GLCO = Glochidion coriaceum; HENI $=$ Hedyotis nitida; HYJA = Hydrocotyle javanica; ILKN = Ilex knucklesensis, ISKU = Isachne kunthiana; KYBR = Kyllinga brevifolia; LESP = Leucaena sp.; LEBI = Leucas biflora; LOTR = Lobelia trigona; LUDE = Ludwigia decurrens, MAIN = Macaranga indica; MAPE = Macaranga peltata; MAESA $=$ Maesa indica; MEMA = Melastoma malabathricum; MISC = Mikania scandens, MIIN = Mimosa sp $;$ NEMO = Neanotis monosperma; OLCA = Old enlandia carymbosa; OSRU = Osbeckia rubicunda OXDE $=$ Oxalis debilis, $\mathrm{PHDE}=$ Phyllanthus debilis PIMI $=$ Pilea microphylla; $\mathrm{PLNI}=$ Plec tranthus nigrescens, $\mathrm{POTR}=$ Pouzolzia triandra $\mathrm{RADE}=$ Rauvolfia densiflora; $\mathrm{STIN}=$ Stachytarpheta indica; $\mathrm{STVE}=$ Stemodia verticillata; SYCO = Symplocos cochinchinensis, TOCY = Torenia cyanea; UN1. = Unknown spp.; and VIPI = Viola pilosa.

Figure 6. Non-metric multidimensional scaling ordination diagram of species scores and environmental variables. The environmental variables associated with variation in tree species composition was canopy openness (Cop).

composition of soil seed banks with that of the standing tree $(\geq 5 \mathrm{~cm} \mathrm{DBH})$ communities, were higher for $\mathrm{CP}$ than NF in both dry and wet seasons, and in the data pooled across both seasons (Table 1). However, values of Sørensen's index were relatively low $(\leq 0.32)$ in all cases.

\subsection{Non-Native Plant Species in Soil Seed Banks}

The non-native species Austroeupatorium inulifolium (Kunth) R. M. King and H. Rob., Ageratina riparia (Regal) R. M. King and H. Rob., Elettaria cardamomum var. cardamomum and Leucaena sp. species constituted 0.4\%, 1.4\%, 1.1\% and $<0.1 \%$ (i.e. $36,124,99$ and 3 emergents from the total of 8906 ) of all emer- 
gents respectively in the $\mathrm{CP}$; and $0.7 \%, 0.6 \%, 0.0 \%$ and $0.3 \%(5,4,0,2$ emergents of the total 714), of all emergents in soil from NF, respectively (Table 3 ). The density and relative abundance (\%) of $A$. inulifolium and Leucaena sp. seeds were not different between $\mathrm{CP}$ and NF, or between seasons. The density and relative abundance of $A$. riparia and $E$. cardamomum seeds were higher in soil from the CP than in that from the NF in both dry and wet seasons. Overall, the relative abundance and density of the seeds of all non-native species (pooled data) were higher in the soils of CP than NF (Table 3).

\section{Discussion}

The cultivation of perennial crops beneath the canopies of tropical forests is a long-standing practice, and the extent of forests affected is increasing as landscapes become more intensively used across all tropical regions. In some cases, these crops will become subsequently abandoned as at our study site in Sri Lanka, although this is rarely quantified. For cardamom, there are published records of plantations in natural forests in India, Lao, Cambodia, Vietnam, Thailand, Costa Rica, Guatemala, El Salvador and Tanzania. Other crops that have analogous management regimes include Brazil nut (Bertholletia excelsa Humb. and Bonpl.), coffee (Coffea spp.), Benzoin (Styrax paralleloneurum Perkins), rubber (Hevea brasiliensis (Willd. ex Adr de Juss.) Muell. et Arg.), cinnamon

Table 3. Relative abundance (\%) and mean density $( \pm \mathrm{SE})$ per sample of non-native species and their statistical significance in the soil seed banks of cardamom plantation (CP) and natural forest (NF) during dry and wet seasons, and in data pooled across both seasons. The statistical significance is evaluated using $\mathrm{P}$ value, considering value $<0.05$ as significant.

\begin{tabular}{|c|c|c|c|c|c|c|c|c|c|c|c|}
\hline \multirow{2}{*}{ Species } & \multicolumn{7}{|c|}{ Relative abundance (\%) } & \multicolumn{2}{|c|}{ Mean density } & \multirow[b]{2}{*}{$\mathrm{df}$} & \multirow[b]{2}{*}{$P$} \\
\hline & Seasons & $\mathrm{CP}$ & NF & $\chi^{2}$ & $\mathrm{df}$ & $P$ & $\mathrm{CP}$ & NF & $\mathrm{t}$ & & \\
\hline \multirow[t]{4}{*}{ Elettaria cardamomum } & Dry & 1.3 & 0.0 & 4.38 & 1 & 0.04 & $1.50 \pm 0.33$ & $0.00 \pm 0.00$ & -276 & 54 & 0.00 \\
\hline & Wet & 0.8 & 0.0 & 4.42 & 1 & 0.03 & $0.56 \pm 0.22$ & $0.00 \pm 0.00$ & -595 & 54 & 0.00 \\
\hline & Pooled & 1.1 & 0.0 & 6.96 & 1 & 0.01 & $1.03 \pm 0.20$ & $0.00 \pm 0.00$ & -471 & 63 & 0.00 \\
\hline & Dry & 0.6 & 1.2 & 1.03 & 1 & 0.31 & $0.73 \pm 0.31$ & $0.62 \pm 0.26$ & 1.77 & 54 & 0.12 \\
\hline \multirow{2}{*}{ Austroeupatorium inulifolium } & Wet & 0.0 & 0.0 & 0.00 & - & - & $0.00 \pm 0.00$ & $0.00 \pm 0.00$ & - & - & - \\
\hline & Pooled & 0.4 & 0.7 & 0.76 & 1 & 0.38 & $0.38 \pm 0.19$ & $0.31 \pm 0.15$ & -0.14 & 63 & 0.89 \\
\hline \multirow[t]{3}{*}{ Ageratina riparia } & Dry & 2.1 & 0.0 & 7.86 & 1 & 0.01 & $2.05 \pm 0.75$ & $0.00 \pm 0.00$ & -3.01 & 54 & 0.03 \\
\hline & Wet & 0.2 & 1.4 & 4.01 & 1 & 0.04 & $0.15 \pm 0.07$ & $0.50 \pm 0.04$ & 2.42 & 54 & 0.04 \\
\hline & Pooled & 1.4 & 0.6 & 5.47 & 1 & 0.03 & $1.28 \pm 0.45$ & $0.25 \pm 0.20$ & -2.97 & 63 & 0.00 \\
\hline \multirow[t]{3}{*}{ Leucaena sp. } & Dry & 0.1 & 0.2 & 0.19 & 1 & 0.66 & $0.06 \pm 0.04$ & $0.12 \pm 0.10$ & 0.61 & 54 & 0.54 \\
\hline & Wet & 0.0 & 0.3 & 2.31 & 1 & 0.13 & $0.00 \pm 0.00$ & $0.12 \pm 0.12$ & 3.70 & 54 & 0.07 \\
\hline & Pooled & 0.0 & 0.3 & 3.71 & 1 & 0.06 & $0.03 \pm 0.02$ & $0.13 \pm 0.08$ & 1.54 & 110 & 0.13 \\
\hline \multirow[t]{3}{*}{ All non-native species } & Dry & 4.0 & 1.4 & 6.47 & 1 & 0.01 & $1.68 \pm 0.26$ & $0.10 \pm 0.08$ & 2.43 & 168 & 0.02 \\
\hline & Wet & 1.0 & 1.7 & 0.58 & 1 & 0.45 & $0.18 \pm 0.06$ & $0.14 \pm 0.12$ & -1.70 & 119 & 0.24 \\
\hline & Pooled & 2.9 & 1.5 & 4.03 & 1 & 0.04 & $0.93 \pm 0.14$ & $0.11 \pm 0.07$ & -2.47 & 399 & 0.04 \\
\hline
\end{tabular}


(Cinnamomum verum Presl.) and cocoa (Theobroma cacao L.). The total area of these crops under cultivation across the tropics is likely to be substantial and increasing, therefore this study is representative of an increasingly important disturbance regime globally.

Cultivation of cardamom in the understorey of a Sri Lankan lower montane rain forest increased the density and changed the composition and diversity of seeds in the soil seed bank. The management adopted for cardamom cultivation increased the abundance of seeds of forbs, grasses, some light demanding tree and shrub species, and non-native species, and these effects persisted even 25 years after active management of the cardamom plantation had ceased. These results are consistent with other studies showing that frequent and/or intense disturbance to forests increases the density and alters the species composition of buried seeds (Leckie et al., 1999; Quintana-Ascencio et al., 1996; Sousa et al., 2017), although no other studies have demonstrated this phenomenon for forests disturbed by cultivation of understorey perennial crops such as cardamom or ginger.

A direct comparison of soil seed bank densities across studies is difficult because of the different sampling depths used in different studies and the inclusion of surface litter in the samples of many studies (see Garwood, 1989). However, the density of seeds in the soil of the abandoned cardamom plantations sampled in Sri Lanka is comparable with that in other disturbed or secondary tropical forests where seeds of weedy species are predominant. For example, QuintanaAscencio et al. (1996) reported a seed bank density of 4000 seeds $\mathrm{m}^{-2}$ for disturbed tropical rain forest in Mexico, while Butler \& Chazdon (1998) found 4535 seeds $\mathrm{m}^{-2}$ in soils of secondary tropical wet forest in Costa Rica. The density of seeds in the soil of relatively undisturbed natural forest at our study site $(2231 \pm$ 184 seeds $\mathrm{m}^{-2}$ ) falls within the range reported for mature tropical forests in other studies, such as the values of 720 - 2341 seeds $\mathrm{m}^{-2}$ for lower montane forest (Williams-Linera, 1993) and 873 - 3632 seeds $\mathrm{m}^{-2}$ for tropical cloud forest (Alvarez-Aquino et al., 2005) in Mexico.

The higher density of seeds in the soil of the abandoned cardamom plantations (CP) than natural forest (NF) at our study site is likely to be associated with an increase in the canopy openness of the CP and a consequent rise in the abundance of forbs and grasses in the ground layer vegetation. Studies elsewhere have also documented a positive response of herbaceous plant abundance to an increase in resource availability, particularly light, resulting from canopy opening (e.g., Lindgren et al., 2006; Thomas et al., 1999).

Allochthonous seed rain from adjacent pastures and cultivated areas influence the soil seed banks of tropical forest fragments (Dalling \& Denslow, 1998; Dupuy \& Chazdon, 1998; Quintana-Ascencio et al., 1996; Young et al., 1987). Our study sites are located within $1 \mathrm{~km}$ of extensive grasslands established on abandoned tea plantations, and within $600 \mathrm{~m}$ of a road. Therefore, it is possible that the density of grasses and forbs has been elevated in both forest types compared to more remote sites. Hence the dispersal of seeds by animals and wind from 
sources in adjacent agricultural land, as well as reproduction of plants already established within the forest both increase the density of soil seed bank. However, our data suggest that any influence of these factors was not sufficient to obscure the effect of cardamom cultivation. In addition to an increase in the abundance of herbaceous plants, higher inputs of the seeds of light-demanding trees such as Macaranga indica and non-native species such as Ageratina riparia have contributed to the higher density of seeds in the soil seed bank of the CP. These higher inputs result from an increase in the relative abundance of adult individuals of herbs, light-demanding trees and non-native shrubs in the plant community comprising the cardamom plantation (Dhakal, 2011).

Trees represented only $18 \%$ and $15 \%$ of all seeds in the soil of cardamom plantations and natural forests respectively. Undisturbed forests tend to have a higher proportion of tree seeds in the seed bank than disturbed forests (Garwood, 1989; Leckie et al., 1999). As in studies elsewhere (Kennedy \& Swaine, 1992; Rico-Gray \& Garcia-Franco, 1992), seeds of late-successional tree species were almost entirely absent from the soil seed banks of either CP or NF, which can be attributed to seed predation, their tendency to germinate quickly, and their lack of seed dormancy (Dupuy \& Chazdon, 1998; Hall \& Swaine, 1980; Hopkins \& Graham, 1983; Leckie et al., 1999; Miller, 1999). In addition, many tropical tree species reproduce at irregular supra-annual intervals (Ashton et al., 1988; Connell \& Green, 2000; Hart, 1995; Metz et al., 2008) and a lack of synchrony between fruit production of late-successional species and the time when the seed bank was sampled would lead to under-representation of these species in the sample. This combination of factors might explain the low correspondence in the composition of tree species in the soil seed banks and the standing tree community in both CP and NF (Table 1), which is consistent with studies of both disturbed and undisturbed tropical forests (Dalling \& Denslow, 1998; Dupuy \& Chazdon, 1998; Roberts, 1981; Tekle \& Bekele, 2000).

Cardamom plantations had a greater similarity in the species composition of trees in the soil seed bank and the standing tree community than natural forests, which is partially explained by the representation of light-demanding species in both above- and below-ground communities in CP but not NF. For example, the seeds of early-successional light-demanding species such as Macaranga peltata and $M$. indica were present in the soils of abandoned cardamom plantations, but absent from the seed banks of adjacent natural forests. This result reflects the much greater abundance of established trees of these species in the CP (Dhakal et al., 2012). Other studies of montane forest have reported an increased emergence of pioneer species after soil-surface disturbance from clearance of understorey by humans (Williams-Linera et al., 2016; Osumi \& Sakurai, 1997; Williams-Linera, 1990).

Seeds of the non-native species A. riparia and Elettaria cardamomum were present at higher densities in the soil of cardamom plantation than natural forest. The greater abundance of the Elettaria presumably reflects increasing propagule pressure arising from reproduction of the residual cardamom plants, 
while a higher density of $A$. riparia suggests that disturbance associated with cardamom cultivation may increase the likelihood of non-native species invading the forest community. This finding supports the hypothesis that disturbance increases the risk of colonisation by non-native invasive species (Dalling \& Denslow, 1998; Lin et al., 2006; Tang et al., 2006). Taken together, the higher abundance of herbs, light-demanding trees and non-native species in the seed banks of CP than NF explains their separation into distinct clusters in ordination space, and suggests that they represent distinct floristic communities. This distinction is not explained by variation in altitude among plots, but is associated with differences in canopy openness of plots between the two forest types.

The pattern of species richness and diversity of the soil seed banks of cardamom plantations and natural forest were not consistent between seasons. Soil seed banks had higher species richness and diversity in abandoned cardamom plantations than natural forests during the dry season, but these contrasts were reversed in the wet season. Some studies carried out in disturbed tropical forests have found that the addition of pioneer species to the tree community can increase the species diversity and richness of the soil seed bank (Arevalo \& Fernandez-Palacios, 2000; Quintana-Ascencio et al., 1996), but in our study system the number of light-demanding species added to the tree community is not sufficient to offset the reduction in species richness associated with disturbance. This comparison is limited by the relatively low number of samples taken from $\mathrm{NF}$, which resulted in the species accumulation curves failing to reach an asymptote. Therefore, it remains possible that the relative difference in species richness between forest types for larger sample sizes would be lower than recorded by us, or even reversed.

\section{Conclusion and Implications for Conservation}

Cardamom cultivation affected the density and community structure of soil seed banks in a tropical lower montane forest in Sri Lanka. The higher density and/or percentage of the seeds of grasses and forbs in cardamom plantations might increase the abundance of seedling germinants representing these life-forms relative to germinants of trees. The low similarity in the composition of the soil seed bank and that of the standing tree community, and the absence of most tree species from the soil seed bank of the abandoned cardamom plantation, implies that the seed bank is an unlikely source of propagules for restoring the tree community to its former condition in the undisturbed forest. Instead, restoration strategies that rely on other sources of propagules, such as protection of newly dispersed seeds or enrichment planting of seedlings, require further investigation in order to define management prescriptions for forest restoration and biodiversity conservation.

\section{Acknowledgements}

My special thanks go to Profs David Burslem and Michelle Pinard for their 
guidance and help throughout this study. I also thank Profs Nimal Gunatilleke and Savitri Gunatilleke for their support in the field. I thank the Darwin Initiative (Project No. 15010) for financial support and the Forest Department of Sri Lanka for granting permission to carry out research in the Knuckles Conservation Area. I am also grateful to Midland State Plantation for allowing us to carry out research in the estates' cardamom plantations.

\section{References}

Alvarez-Aquino, C., Williams-Linera, G., \& Newton, A. C. (2005). Disturbance Effects on the Seed Bank of Mexican Cloud Forest Fragments. Biotropica, 37, 337-342.

https://doi.org/10.1111/j.1744-7429.2005.00044.x

Anon (2000). Gazette. Democratic Socialist Republic of Sri Lanka No. 1130/22, 5 May 2000.

Anon (2002). Cardamom: Cultivation and Processing. Technical Bulletin 6, The Department of Export Agriculture, Sri Lanka.

Arevalo, J. R., \& Fernandez-Palacios, J. M. (2000). Seed Bank Analysis of Tree Species in Two Stands of the Tenerife Laurel Forest (Canary Islands). Forest Ecology and Management, 130, 177-185. https://doi.org/10.1016/S0378-1127(99)00182-6

Ashton, M. S., Gunatilleke, C. V. S., Singhakumara, B. M. P., \& Gunatilleke, I. A. U. N. (2001). Restoration Pathways for Rain Forest in Southeast Sri Lanka: A Review of Concepts and Models. Forest Ecology and Management, 154, 409-430. https://doi.org/10.1016/S0378-1127(01)00512-6

Ashton, P. S., Givinish, T. J., \& Appanah, S. (1988). Staggered Flowering in the Dipterocarpaceae: New Insights into Floral Induction and the Evolution of Mast Fruiting in the Aseasonal Tropics. American Naturalist, 132, 44-66. https://doi.org/10.1086/284837

Balasubramaniam, S. (1988). The Major Forest Formations of the Knuckles Region. Paper presented on the Preliminary Workshop for the Preparation of a Conservation Plan for the Knuckles Range of Forests, Colombo, Sri Lanka: Forest Department.

Bambaradeniya, C. N. B., \& Ekanayake, S. P. (2003). A Guide to the Biodiversity of Knuckles Forest Region. Colombo, Sri Lanka: IUCN, The World Conservation Union, Sri Lanka Country Office.

Bandaratillake, H. M. (2005). The Knuckles Range: Protecting Livelihoods, Protecting Forests. In P. B. Durst, C. Brown, H. Tacio, \& M. Ishikawa (Eds.), In Search of Excellence Exemplary Forest Management in Asia and the Pacific, RAP Publication 2005/02, Bangkok: FAO of the United Nations, Regional Office for Asia and the Pacific and RECOFTC for Asia and the Pacific.

Bhagwat, S. A., Willis, K. J., Birks, H. J., \& Wittaker, R. J. (2008). Agroforesty: A Refuge for Tropical Biodiversity? Trends in Ecology and Evolution, 23, 261-267.

https://doi.org/10.1016/j.tree.2008.01.005

Buckhingham, S. (2004). Community Based Conservation in the Hoang Lien Mountains. Synthesis Report on Cardamom Cultivation, Flora and Fauna International.

Butler, B. J., \& Chazdon, R. L. (1998). Species Richness, Spatial Variation, and Abundance of the Soil Seed Bank of a Secondary Tropical Rain Forest. Biotropica, 30, 214-222. https://doi.org/10.1111/j.1744-7429.1998.tb00056.x

Chandrashekara, U. M., \& Ramakrishnan, P. S. (1993). Germiable Soil Seed Bank Dynamics during the Gap Phase of a Humid Tropical Forest in the Western Ghats of Kerala, India. Journal of Tropical Ecology, 9, 455-467. 
https://doi.org/10.1017/S0266467400007525

Colwell, R. K. (2006). EstimateS: Statistical Estimates of Species Richness and Shared Species from Samples. Version 8.0, User's Guide and Application. http://purl.oclc.org/estimates

Conn, J. S., Catherine, L. C., \& DeLapp, J. A. (1984). Soil Seed Bank Changes after Forest Clearing and Agricultural Use in Alaska. Weed Science, 32, 343-347.

Connell, J. H., \& Green, P. T. (2000). Seedling Dynamics over Thirty-Two Years in a Tropical Rain Forest Tree. Ecology, 81, 568-584. https://doi.org/10.1890/0012-9658(2000)081[0568:SDOTTY]2.0.CO;2

Dalling, J. W., \& Denslow, J. S. (1998). Soil Seed Bank Composition along a Forest Chronosequence in Seasonally Moist Tropical Forest, Panama. Journal of Vegetation Science, 9, 669-678. https://doi.org/10.2307/3237285

Decocq, G., Valentin, B., \& Toussaint, B. (2004). Soil Seed Bank Composition and Diversity in a Managed Temperate Deciduous Forest. Biodiversity \& Conservation, 13, 24852509. https://doi.org/10.1023/B:BIOC.0000048454.08438.c6

Denslow, J. S., Amanda, L. U., \& Hughes, R. F. (2006). Limitations to Seedling Establishment in a Mesic Hawaiian Forest. Oecologia, 148, 118-128. https://doi.org/10.1007/s00442-005-0342-7

Dhakal, B. (2011). Protected Forest Under-Planted with Cardamom: Impacts and Opportunities for Conservation and Livelihoods. $\mathrm{PhD}$ Thesis, Aberdeen, UK: University of Aberdeen.

Dhakal, B., Pinard, M. A., Gunatilleke, I. A. U. N., Gunatilleke, C. V. S., Weerasinghe, H. M. S. P. M., Dharmaparakrama, A. L. S., \& Bruslem, D. F. R. P. (2012). Impacts of Cardamom Cultivation on Montane Forest Ecosystems in Sri Lanka. Forest Ecology and Management, 274, 151-160. https://doi.org/10.1016/j.foreco.2012.02.021

Dupuy, J. M., \& Chazdon, R. L. (1998). Long-Term Effects of Forest Regrowth and Selective Logging on the Seed Bank of Tropical Forest in NE Costa Rica. Biotropica, 30, 223-237. https://doi.org/10.1111/j.1744-7429.1998.tb00057.x

Elliott, K. J., \& Swank, W. T. (2008). Long-Term Changes in Forest Composition and Diversity Following Early Logging (1919-1923) and the Decline of American Chestnut (Castanea dentata). Plant Ecology, 197, 155-172. https://doi.org/10.1007/s11258-007-9352-3

Garwood, N. C. (1989). Tropical Soil Seed Banks: A Review. In M. A. Leck, V. T. Parker, \& R. L. Simpson (Eds.), Ecology of Soil Seed Banks (pp. 9-21). San Diego, CA: Academic Press Inc. https://doi.org/10.1016/b978-0-12-440405-2.50014-2

Guariguata, M. R., \& Ostertag, R. (2001). Neotropical Secondary Forest Succession: Changes in Structural and Functional Characteristics. Forest Ecology and Management, 148, 185-206. https://doi.org/10.1016/S0378-1127(00)00535-1

Gunaratne, A. M. T. A. (2007). Factors Inhibiting Succession in Degraded Grasslands in the Knuckles Forest Reserve, Sri Lanka. PhD Thesis, Aberdeen, UK: University of Aberdeen.

Gunawardane, A. (2003). Ecological Implications of Cardamom Cultivation in the High Attitudes of Knuckles Forest Reserve, Central Province, Sri Lanka. The Sri Lanka Forester, 26, 1-9.

Gurusinghe, PdeA. (1988). Cardamom Cultivation in the Knuckles Range. A paper presented at the Workshop on Preparation of a Management Plan for Conservation of Knuckles Forest, Colombo, Sri Lanka.

Hall, J. B., \& Swaine, M. D. (1980). Seeds Stocks in Ghanaian Forest Soils. Biotropica, 12, 
256-263. https://doi.org/10.2307/2387695

Hansen, M. J., \& Clevenger, A. P. (2005). The Influence of Disturbance and Habitat on the Presence of Non-Native Plant Species along Transport Corridors. Biological Conservation, 125, 249-259. https://doi.org/10.1016/j.biocon.2005.03.024

Hart, T. B. (1995). Seed, Seedling and Sub-Canopy Survival in Monodominant and Mixed Forests of the Ituri Forest, Africa. Journal of Tropical Ecology, 11, 443-459. https://doi.org/10.1017/S0266467400008919

Hopkins, M. S., \& Graham, A. W. (1983). The Species Composition of Soil Seed Banks beneath Lowland Tropical Rainforests in North Queensland, Australia. Biotropica, 15, 90-99. https://doi.org/10.2307/2387950

IUCN (1994). Management Plan for the Conservation of the Knuckles Forest. Phase II. Sri Lanka: IUCN, The World Conservation Union in collaboration with the Forest Department of the Ministry of Forestry, Irrigation and Mahaweli Development.

Kennedy, D. N., \& Swaine, M. D. (1992). Germination and Growth of Colonizing Species in Artificial Gaps of Different Sizes in Dipterocarp Rain-Forest. Philosophical Transactions of the Royal Society of London, Series B, 335, 357-366.

https://doi.org/10.1098/rstb.1992.0027

Kumar, B. M., Kumar, V. S., \& Mathew, T. (1995). Floristic Attributes of Small Cardamom (Elettaria cardamomum L. Maton) Growing Areas in the Western Ghats of Peninsular India. Agroforestry Systems, 31, 275-289. https://doi.org/10.1007/BF00712079

Leckie, S., Velled, M., Bell, G., Waterway, M. J., \& Lechowicz, M. J. (1999). The Seed Bank in an Old-Growth, Temperate Deciduous Forest. Canadian Journal of Botany, 78, 181191.

Lemenih, M., \& Teketay, D. (2006). Changes in Soil Seed Bank Composition and Density Following Deforestation and Subsequent Cultivation of a Tropical Dry Afromontane Forest in Ethiopia. Tropical Ecology, 47, 1-12.

Lin, L., Cao, M., He, Y., Baskin, J. M., \& Baskin, C. (2006). Nonconstituent Species in Soil Seed Bank as Indicators of Anthropogenic Disturbance in Forest Fragments. Canadian Journal of Forestry Research, 36, 2300-2316. https://doi.org/10.1139/x06-137

Lindgren, P. M. F., Ransome, D. B., Sullivan, D. S., \& Sullivan, T. P. (2006). Plant Community Attributes 12 to 14 Years Following Precommercial Thinning in a Young Lodgepole Pine Forest. Canadian Journal of Forest Research, 36, 48-61. https://doi.org/10.1139/x05-228

Martins, A. M., \& Engel, V. L. (2007). Soil Seed Banks in Tropical Forest Fragments with Different Disturbance Histories in South-Eastern Brazil. Ecological Engineering, 31, 165-174. https://doi.org/10.1016/j.ecoleng.2007.05.008

McCune, B., \& Grace, J. (2002). Analysis of Ecological Communities. Glenden Beach, OR: MjM Software Design.

Metcalfe, D. J., \& Turner, I. M. (1998). Soil Seed Bank from Lowland Rain Forest in Singapore: Canopy-Gap and Litter-Gap Demanders. Journal of Tropical Ecology, 14, 103-108. https://doi.org/10.1017/S0266467498000091

Metz, M. R., Comita, L. S., Chen, Y. Y., Norden, N., Condit, R., Hubbell, S. P., Sun, I., Noor, N. S. M., \& Wright, S. J. (2008). Temporal and Spatial Variability in Seedling Dynamics: A Cross-Site Comparison in Four Lowland Tropical Forests. Journal of Tropical Ecology, 24, 9-18. https://doi.org/10.1017/S0266467407004695

Moffatt, S. F., McLachlan, S. M., \& Kenkel1, N. C. (2004). Impacts of Land Use on Riparian Forest along an Urban-Rural Gradient in Southern Manitoba. Plant Ecology, 174, 119-135. https://doi.org/10.1023/B:VEGE.0000046055.27285.fd 
MSP (2009). Climatic Data of Midland State Plantation (Unpublished Data). Sri Lanka: Midland State Plantation.

Nybe, E. V., Mini Raj, N., \& Peter, K. V. (2007). Spices. In K. V. Peter (Ed.), Horticulture Science Series (Vol. 5, pp. 159-164). New Delhi: New India Publishing Agency.

Osumi, K., \& Sakurai, S. (1997). Seedling Emergence of Betula maximowicziana Following Human Disturbance and the Role of Buried Viable Seeds. Forest Ecology and Management, 93, 227-234. https://doi.org/10.1016/S0378-1127(96)03963-1

Parthasarathy, N. (1999). Tree Diversity and Distribution in Undisturbed and Human-Impacted Sites of Tropical Wet Evergreen Forest in Southern Western Ghats, India. Biodiversity and Conservation, 8, 1365-1381. https://doi.org/10.1023/A:1008949407385

Pascarella, J. B., Aide, T. M., Serrano, M. I., \& Zimmerman, J. K. (2000). Land-Use History and Forest Regeneration in the Cayey Mountains, Puerto Rico. Ecosystems, 3, 217-228. https://doi.org/10.1007/s100210000021

Peterson, C. J., \& Carson, W. P. (1996). Generalizing Forest Regeneration Models: The Dependence of Propagule Availability on Disturbance History and Stand Size. Canadian Journal of Forest Research, 26, 45-52. https://doi.org/10.1139/x26-005

Pickett, S. T. A., \& McDonnell, M. J. (1989). Seed Bank Dynamics in Temperate Deciduous Forest. In M. A. Leck, V. T. Parker, \& R. L. Simpson (Eds.), Ecology of Soil Seed Banks (pp. 123-124). San Diego, CA: Academic Press Inc. https://doi.org/10.1016/B978-0-12-440405-2.50013-0

Quintana-Ascencio, P. F., Gonzalez-Espinosa, M., Ramirez-Marcial, N., DominguezVazquez, G., \& Martinez-Ico, M. (1996). Soil Seed Banks and Regeneration of Tropical Rain Forest from Milpa Fields at the Selva Lacandona, Chiapas, Mexico. Biotropica, 28, 192-209. https://doi.org/10.2307/2389074

R Core Development Team (2010). R: A Language and Environment for Statistical Computing. R Foundation for Statistical Computing, Vienna, Austria. http://www.R-project.org

Reyes, T., Luukkanen, O., \& Quiroz, R. (2006). Small Cardamom-Precious for People, Harmful for Mountain Forests. Mountain Research and Development, 26, 131-137. https://doi.org/10.1659/0276-4741(2006)26[131:SCFPHF]2.0.CO;2

Richter, R., \& Stromberg, J. C. (2005). Soil Seed Banks of Two Montane Riparian Areas: Implications for Restoration. Biodiversity and Conservation, 14, 993-1016. https://doi.org/10.1007/s10531-004-7844-1

Rico-Gray, V., \& Garcia-Franco, J. G. (1992). Vegetation and Soil Seed Bank of Successional Stages in Tropical Lowland Deciduous Forest. Journal of Vegetation Science, 3, 617-624. https://doi.org/10.2307/3235828

Rivera, L. W., \& Aide, T. M. (1998). Forest Recovery in the Karst Region of Puerto Rico. Forest Ecology and Management, 108, 63-75. https://doi.org/10.1016/S0378-1127(97)00349-6

Rivera, L. W., Zimmermann, J. K., \& Aide, T. M. (2000). Forest Recovery in Abandoned Agricultural Lands in a Karst Region of the Dominican Republic. Plant Ecology, 148, 115-125. https://doi.org/10.1023/A:1009825211430

Roberts, H. A. (1981). Seed Banks in Soil. Advanced Applied Biology, 6, 1-55.

Saulei, S. M., \& Swaine, M. D. (1988). Rain Forest Seed Dynamics during Succession at Gogol, Papua New Guinea. Journal of Ecology, 76, 1133-1152. https://doi.org/10.2307/2260639

Schroth, G., \& da Mota, M. S. S. (2013). Agroforestry: Complex Multi-Strata Agriculture. 
In N. van Alfen (Ed.), Encyclopedia of Agriculture and Food Systems. Oxford: Elsevier. (In press)

Sousa, T. R., Costa, F. R. C., Bentos, T. V., Filho, N. L., Mesquita, R. C. G., \& Ribeiro, I. O. (2017). The Effect of Forest Fragmentation on the Soil Seed Bank of Central Amazonia. Forest Ecology and Management, 393, 105-112. https://doi.org/10.1016/j.foreco.2017.03.020

Swaine, M. D., \& Hall, J. B. (1983). Early Succession on Cleared Forest Land in Ghana. Journal of Ecology, 71, 601-627. https://doi.org/10.2307/2259737

Tang, Y., Cao, M., \& Fu, X. H. (2006). Soil Seed Bank in a Dipterocarp Rain Forest in Xishuangbanna, SW China. Biotropica, 38, 328-333. https://doi.org/10.1111/j.1744-7429.2006.00149.x

Tekle, K., \& Bekele T. (2000). The Role of Soil Seed Banks in the Rehabilitation of Degraded Hillslopes in Southern Wello, Ethiopia. Biotropica, 32, 23-32. https://doi.org/10.1111/j.1744-7429.2000.tb00444.x

ter Steege, H. (1996). Winphot 5: A Program to Analyze Vegetation Indices, Light and Light Quality from Hemispherical Photographs. Tropenbos Guyana Reports 95-2, Georgetown, GU: Tropenbos Guyana Programme.

Thomas, S. C., Halpern, C. B., Falk, D. A., Liguori, D. A., \& Austin, K. A. (1999). Plant Diversity in Managed Forests: Understory Responses to Thinning and Fertilization. Ecological Applications, 9, 864-879. https://doi.org/10.1890/1051-0761(1999)009[0864:PDIMFU]2.0.CO;2

Thompson, K. (1992). Functional Ecology of Soil Seed Banks. In M. Fenner (Ed.), Seeds. The Ecology of Regeneration in Plant Communities (pp. 231-258).

Uhl, C., Clark, H., \& Murphy, P. (1981). Early Plant Succession after Cutting and Burning in the Upper Rio Negro Region of the Amazon Basin. Journal of Ecology, 69, 631-649. https://doi.org/10.2307/2259689

Wang, W. J., Ren, H., Yang, L., Li, D., \& Guo, Q. (2009). Soil Seed Banks in Four 22-Year-Old Plantations in South China: Implications for Restoration. Forest Ecology and Management, 258, 2000-2006. https://doi.org/10.1016/j.foreco.2009.07.049

Williams, C. B. (1947). The Logarithmic Series and Its Application to Biological Problems. Journal of Ecology, 34, 253-272. https://doi.org/10.2307/2256719

Williams-Linera, G. (1990). Origin and Early Development of Forest Edge Vegetation in Panama. Biotropica, 22, 235-241. https://doi.org/10.2307/2388533

Williams-Linera, G. (1993). Soil Seed Banks in Four Lower Montane Forests of Mexico. Journal of Tropical Ecology, 9, 321-337. https://doi.org/10.1017/S0266467400007379

Williams-Linera, G., Bonilla-Moheno, M., \& López-Barrera, F. (2016). Tropical Cloud Forest Recovery: The Role of Seed Banks in Pastures Dominated by an Exotic Grass. New Forests, 47, 481-496. https://doi.org/10.1007/s11056-016-9526-8

Young, K. R., Ewel, J. J., \& Brown, B. J. (1987). Seed Dynamics during Forest Succession in Costa Rica. Vegetatio, 71, 157-173.

Zuur, A. F., Ieno, E. N., Walker, N. J., Saveliev, A. A., \& Smith, G. M. (2009). Mixed Effects Models and Extensions in Ecology with R. Berlin: Springer Publications. https://doi.org/10.1007/978-0-387-87458-6 


\section{Appendices: Supplementary Data}

Table A1. Total number of emergents from soil seed bank samples taken from abandoned cardamom plantations (CP) and natural forests (NF) in lower montane forests in Sri Lanka in the dry (August) and wet (February) seasons and for pooled data from these two seasons. Late-successional tree species are indicated by an asterisk.

\begin{tabular}{|c|c|c|c|c|c|c|c|c|c|}
\hline \multirow{3}{*}{ Family } & \multirow{3}{*}{ Species } & \multirow{3}{*}{ Life-forms } & \multicolumn{7}{|c|}{ Total number of emergents } \\
\hline & & & \multicolumn{3}{|c|}{ Dry season } & \multicolumn{3}{|c|}{ Wet season } & \multirow{2}{*}{$\begin{array}{l}\text { Grand } \\
\text { Total }\end{array}$} \\
\hline & & & $\mathrm{CP}$ & NF & Total & $\mathrm{CP}$ & NF & Total & \\
\hline Amaranthaceae & Aerva lanata & forb & 6 & & 6 & & & 0 & 6 \\
\hline Amaranthaceae & Amaranthus oleraceus & forb & 24 & 4 & 28 & 122 & 20 & 142 & 170 \\
\hline Apiaceae & Hydrocotyle javanica & climber & 10 & & 10 & 2 & & 2 & 12 \\
\hline Apocynaceae & Rauvolfia densiflora & tree & 4 & & 4 & & & 0 & 4 \\
\hline Aquifoliaceae & Ilex knucklesensis & tree & 8 & & 8 & & 1 & 1 & 9 \\
\hline Asteraceae & Ageratum conyzoides & forb & 81 & 10 & 91 & 111 & 18 & 129 & 220 \\
\hline Asteraceae & Crassocephalum crepidioides & forb & 140 & 7 & 147 & 43 & 5 & 48 & 195 \\
\hline Asteraceae & Elephantopus scaber & forb & 18 & 3 & 21 & 10 & 3 & 13 & 34 \\
\hline Asteraceae & Austroeupatorium inulifolium & shrub & 36 & 5 & 41 & & & 0 & 41 \\
\hline Asteraceae & Ageratina riparia & forb & 117 & & 117 & 7 & 4 & 11 & 128 \\
\hline Asteraceae & Mikania scandens & forb & 2 & 2 & 4 & & & 0 & 4 \\
\hline Asteraceae & Psiadia ceylanica & shrub & 2 & & 2 & & & 0 & 2 \\
\hline Campanulaceae & Lobelia trigona & forb & 295 & 46 & 341 & 222 & 4 & 226 & 567 \\
\hline Commelinaceae & Commelina indehiscens & forb & 298 & 22 & 320 & 5 & 1 & 6 & 326 \\
\hline Commelinaceae & Cyanotis cristata & forb & 2 & & 2 & 7 & 1 & 8 & 10 \\
\hline Commelinaceae & Cynotis ceylanica & forb & 39 & 16 & 55 & 12 & 10 & 22 & 77 \\
\hline Cyperaceae & Cyperus compressus & grass & 2 & 1 & 3 & & & 0 & 3 \\
\hline Cyperaceae & Cyperus iria & grass & 561 & 12 & 573 & 282 & 6 & 288 & 861 \\
\hline Cyperaceae & Cyperus rotundus & grass & 506 & 49 & 555 & 18 & & 18 & 573 \\
\hline Cyperaceae & Fimbristylis falcata & grass & 3 & & 3 & & & 0 & 3 \\
\hline Сyperaceae & Kyllinga brevifolia & grass & 17 & & 17 & & 2 & 2 & 19 \\
\hline Euphorbiaceae & Euphorbia thymifolia & forb & 42 & 6 & 48 & 75 & 13 & 88 & 136 \\
\hline Euphorbiaceae & Macaranga indica & tree & 26 & & 26 & 67 & & 67 & 93 \\
\hline Euphorbiaceae & Macaranga peltata & tree & 3 & & 3 & 8 & & 8 & 11 \\
\hline Euphorbiaceae & Phyllanthus debilis & shrub & 1 & & 1 & & & 0 & 1 \\
\hline Fabaceae & Desmodium heterophyllum & forb & 37 & & 37 & 4 & & 4 & 41 \\
\hline Fabaceae & Desmodium sp. & forb & 3 & & 3 & & & 0 & 3 \\
\hline Fabaceae & Erythrina subumbrans & tree & & & 0 & 1 & & 1 & 1 \\
\hline Fabaceae & Leucaena sp. & tree & 3 & 1 & 4 & & 1 & 1 & 5 \\
\hline Lamiaceae & Leucas biflora & forb & 12 & & 12 & 32 & 7 & 39 & 51 \\
\hline Lamiaceae & Plectranthus nigrescens & forb & 40 & & 40 & & & 0 & 40 \\
\hline Melastomataceae & Melastoma malabathricum & shrub & 63 & 22 & 85 & & & 0 & 85 \\
\hline
\end{tabular}




\section{Continued}

\begin{tabular}{|c|c|c|c|c|c|c|c|c|c|}
\hline Melastomataceae & Osbeckia rubicunda & shrub & 9 & & 9 & 153 & 4 & 157 & 166 \\
\hline Mimosaceae & Mimosa sp. & forb & 3 & & 3 & & & 0 & 3 \\
\hline Moraceae & Ficus hispida & tree & 29 & 2 & 31 & & & 0 & 31 \\
\hline Myrsinaceae & Maesa indica & tree & 566 & 28 & 594 & 698 & 26 & 724 & 1318 \\
\hline Onagraceae & Ludwigia decurrens & forb & 2 & 5 & 7 & 8 & & 8 & 15 \\
\hline Oxalidaceae & Biophytum proliferum & forb & 189 & 7 & 196 & 175 & 19 & 194 & 390 \\
\hline Oxalidaceae & Oxalis debilis & forb & 16 & 4 & 20 & & & 0 & 20 \\
\hline Phyllanthaceae & Glochidion coriaceum $^{*}$ & tree & 6 & & 6 & & 2 & 2 & 8 \\
\hline Poaceae & Brachiaria milliformis & grass & 16 & 2 & 18 & & & 0 & 18 \\
\hline Poaceae & Digitaria adscendens & grass & 6 & 2 & 8 & & & 0 & 8 \\
\hline Poaceae & Eragrostis pilosa & grass & 118 & 11 & 129 & 32 & 1 & 33 & 162 \\
\hline Poaceae & Eragrostis unioloides & grass & 9 & 4 & 13 & 22 & 6 & 28 & 41 \\
\hline Poaceae & Isachne kunthiana & grass & 14 & & 14 & 4 & & 4 & 18 \\
\hline Pteridaceae & Pityrogramma dealbata & fern & 50 & 2 & 52 & 6 & 17 & 23 & 75 \\
\hline Rubiaceae & Hedyotis nitida & forb & 1196 & 34 & 1230 & 575 & 20 & 595 & 1825 \\
\hline Rubiaceae & Neanotis monosperma & forb & 34 & & 34 & & & 0 & 34 \\
\hline Rubiaceae & Oldenlandia corymbosa & forb & 344 & 31 & 375 & 246 & 38 & 284 & 659 \\
\hline Rutaceae & Acronychia pedunculata & tree & 39 & 1 & 40 & 20 & & 20 & 60 \\
\hline Scrophulariaceae & Scoparia dulcis & forb & & & 0 & 4 & & 4 & 4 \\
\hline Scrophulariaceae & Stemodia verticillata & forb & 15 & 5 & 20 & 16 & 4 & 20 & 40 \\
\hline Scrophulariaceae & Torenia cyanea & forb & 129 & 10 & 139 & 16 & 6 & 22 & 161 \\
\hline Symplocaceae & Symplocos cochinchinensis & tree & 29 & & 29 & 1 & & 1 & 30 \\
\hline Ulmaceae & Celtis timorensis & tree & 2 & & 2 & 20 & 4 & 24 & 26 \\
\hline Urticaceae & Debregeasia longifolia & shrub & 134 & 13 & 147 & 50 & 7 & 57 & 204 \\
\hline Urticaceae & Pilea microphylla & forb & 41 & 14 & 55 & 88 & 12 & 100 & 155 \\
\hline Urticaceae & Pouzolzia triandra & forb & 16 & 2 & 18 & 4 & & 4 & 22 \\
\hline Verbenaceae & Stachytarpheta indica & shrub & 11 & 2 & 13 & 6 & & 6 & 19 \\
\hline Violaceae & Viola pilosa & forb & 10 & & 10 & 14 & 7 & 21 & 31 \\
\hline Zingiberaceae & Elettaria cardamomum & forb & 72 & & 72 & 27 & & 27 & 99 \\
\hline Unknown & Unknown sp. sbc11 & fern & & & 0 & 6 & & 6 & 6 \\
\hline Unknown & Unknown sp. sbc22 & forb & 2 & & 2 & & & 0 & 2 \\
\hline Unknown & Unknown sp. sbc32 & forb & & & 0 & 41 & 14 & 41 & 55 \\
\hline Unknown & Unknown sp. sbc35 & forb & & & 0 & 2 & & 2 & 2 \\
\hline Unknown & Unknown sp. sbn32 & forb & & & 0 & & 4 & 4 & 4 \\
\hline Unknown & Unknown sp. sbc3 & shrub & 37 & & 37 & & & 0 & 37 \\
\hline Unknown & Unknown sp. sbc1 & tree & 89 & & 89 & & & 0 & 89 \\
\hline Unknown & Unknown sp. sbc25 & tree & 1 & & 1 & & & 0 & 1 \\
\hline Unknown & Unknown sp. sbc26 & tree & 3 & & 3 & & & 0 & 3 \\
\hline
\end{tabular}




\section{Continued}

\begin{tabular}{|c|c|c|c|c|c|c|c|c|c|}
\hline Unknown & Unknown sp. sbc6 & tree & & & 0 & 3 & & 3 & 3 \\
\hline Unknown & Unknown sp. sbn 21 & tree & & 27 & 27 & & & 0 & 27 \\
\hline Unknown & Unknown sp. sbn22 & tree & & 10 & 10 & & & 0 & 10 \\
\hline Unknown & Unknown sp. sbn31 & tree & & & 0 & & 4 & 4 & 4 \\
\hline Unknown & Unknown sp. sbn33 & tree & & & 0 & & 1 & 1 & 1 \\
\hline Unknown & Unknown sp. sbc21 & unknown & 2 & & 2 & & & 0 & 2 \\
\hline \multirow[t]{2}{*}{ Unknown } & Unknown sp. sbc23 & unknown & 1 & & 1 & & & 0 & 1 \\
\hline & Total & & 5641 & 422 & 6063 & 3265 & 292 & 3557 & 9620 \\
\hline
\end{tabular}

Table A2. Non-metric multidimensional scaling correlations for the soil seed bank species with the first three ordination axes in cardamom plantation and natural forest. Pearson's parametric $(r)$ correlation with ordination axes, $n=103$. Species variable with $r$ $\geq 0.30$ are highlighted in bold.

\begin{tabular}{|c|c|c|c|}
\hline \multirow{2}{*}{ Species } & Axis 1 & Axis 2 & Axis 3 \\
\hline & $\mathrm{r}$ & $\mathrm{r}$ & $\mathrm{r}$ \\
\hline Acronychia pedunculata & -0.08 & 0.05 & -0.10 \\
\hline Aerva lanata & -0.12 & -0.09 & -0.20 \\
\hline Ageratum conyzoides & 0.01 & 0.12 & -0.01 \\
\hline Amaranthus oleraceus & -0.07 & 0.03 & -0.2 \\
\hline Biophytum proliferum & -0.23 & 0.04 & 0.12 \\
\hline Brachiaria milliformis & -0.27 & -0.24 & -0.08 \\
\hline Celtis timorensis & -0.03 & 0.08 & 0.27 \\
\hline Commelina indehiscens & -0.43 & -0.40 & -0.45 \\
\hline Crassocephalum crepidioides & -0.23 & -0.14 & -0.02 \\
\hline Cyanotis cristata & 0.03 & 0.03 & 0.20 \\
\hline Cynotis ceylanica & 0.00 & -0.11 & -0.09 \\
\hline Cyperus compressus & -0.09 & -0.06 & -0.06 \\
\hline Cyperus iria & -0.39 & 0.21 & -0.40 \\
\hline Cyperus rotundus & -0.30 & -0.22 & -0.46 \\
\hline Debregeasia longifolia & -0.17 & -0.01 & 0.08 \\
\hline Desmodium heterophyllum & -0.24 & -0.12 & -0.24 \\
\hline Desmodium species & -0.14 & -0.09 & 0.06 \\
\hline Digitaria adscendens & -0.10 & -0.19 & 0.00 \\
\hline Elephantopus scaber & 0.03 & -0.06 & 0.00 \\
\hline Elettaria cardamomum & -0.33 & 0.12 & -0.29 \\
\hline Eragrostis pilosa & -0.20 & -0.17 & -0.07 \\
\hline Eragrostis unioloides & 0.08 & -0.01 & 0.16 \\
\hline Austroeupatorium inulifolium & -0.01 & -0.09 & -0.21 \\
\hline Ageratina riparia & 0.03 & -0.14 & -0.19 \\
\hline Euphorbia thymifolia & -0.06 & 0.27 & 0.05 \\
\hline
\end{tabular}




\section{Continued}

\begin{tabular}{|c|c|c|c|}
\hline Ficus hispida & -0.33 & -0.20 & -0.30 \\
\hline Glochidion coriaceum & -0.15 & -0.19 & -0.20 \\
\hline Hedyotis nitida & -0.69 & -0.36 & 0.13 \\
\hline Hydrocotyle javanica & -0.27 & -0.12 & 0.12 \\
\hline Ilex knucklesensis & -0.05 & -0.10 & -0.15 \\
\hline Isachne kunthiana & -0.07 & 0.01 & -0.10 \\
\hline Kyllinga brevifolia & -0.03 & -0.07 & -0.10 \\
\hline Leucaena sp. & 0.02 & -0.14 & -0.15 \\
\hline Leucas biflora & 0.01 & 0.17 & 0.14 \\
\hline Lobelia trigona & -0.23 & 0.12 & -0.34 \\
\hline Ludwigia decurrens & 0.14 & -0.11 & -0.01 \\
\hline Macaranga indica & -0.17 & 0.03 & 0.12 \\
\hline Macarnga peltata & 0.08 & -0.01 & -0.08 \\
\hline Maesa indica & -0.50 & 0.50 & 0.22 \\
\hline Melastoma malabathricum & -0.23 & -0.22 & 0.03 \\
\hline Mikania scandens & 0.07 & -0.14 & -0.11 \\
\hline Mimosa sp. & -0.11 & 0.05 & -0.24 \\
\hline Neanotis monosperma & -0.21 & 0.01 & -0.10 \\
\hline Oldenlandia corymbosa & -0.16 & 0.09 & 0.19 \\
\hline Osbeckia rubicunda & -0.05 & 0.31 & 0.13 \\
\hline Oxalis debilis & -0.17 & -0.23 & -0.14 \\
\hline Phyllanthus debilis & -0.05 & -0.03 & -0.13 \\
\hline Pilea microphylla & 0.09 & 0.23 & 0.13 \\
\hline Plectranthus nigrescens & -0.33 & -0.10 & -0.33 \\
\hline Pouzolzia triandra & -0.11 & -0.23 & 0.01 \\
\hline Rauvolfia densiflora & -0.22 & -0.16 & -0.02 \\
\hline Stachytarpheta indica & 0.03 & -0.24 & 0.03 \\
\hline Stemodia verticillata & 0.11 & 0.13 & 0.09 \\
\hline Symplocos cochinchinensis & -0.30 & -0.14 & -0.27 \\
\hline Torenia cyanea & -0.19 & -0.01 & 0.09 \\
\hline Viola pilosa & 0.08 & 0.30 & 0.07 \\
\hline Unknown sp. sbcl & -0.08 & -0.11 & 0.01 \\
\hline Unknown sp. sbc11 & 0.22 & -0.21 & -0.21 \\
\hline Unknown sp. sbc21 & 0.06 & -0.13 & -0.07 \\
\hline Unknown sp. sbc32 & 0.07 & 0.35 & 0.28 \\
\hline Unknown sp. sbc3 & -0.40 & -0.15 & -0.35 \\
\hline Unknown sp. sbc6 & -0.24 & -0.14 & -0.17 \\
\hline Unknown sp. sbn31 & 0.38 & 0.07 & 0.06 \\
\hline Unknown sp. sbn22 & 0.30 & 0.09 & 0.02 \\
\hline
\end{tabular}


Table A3. Abundance of overstorey species recorded in the experimental plots in cardamom plantation.

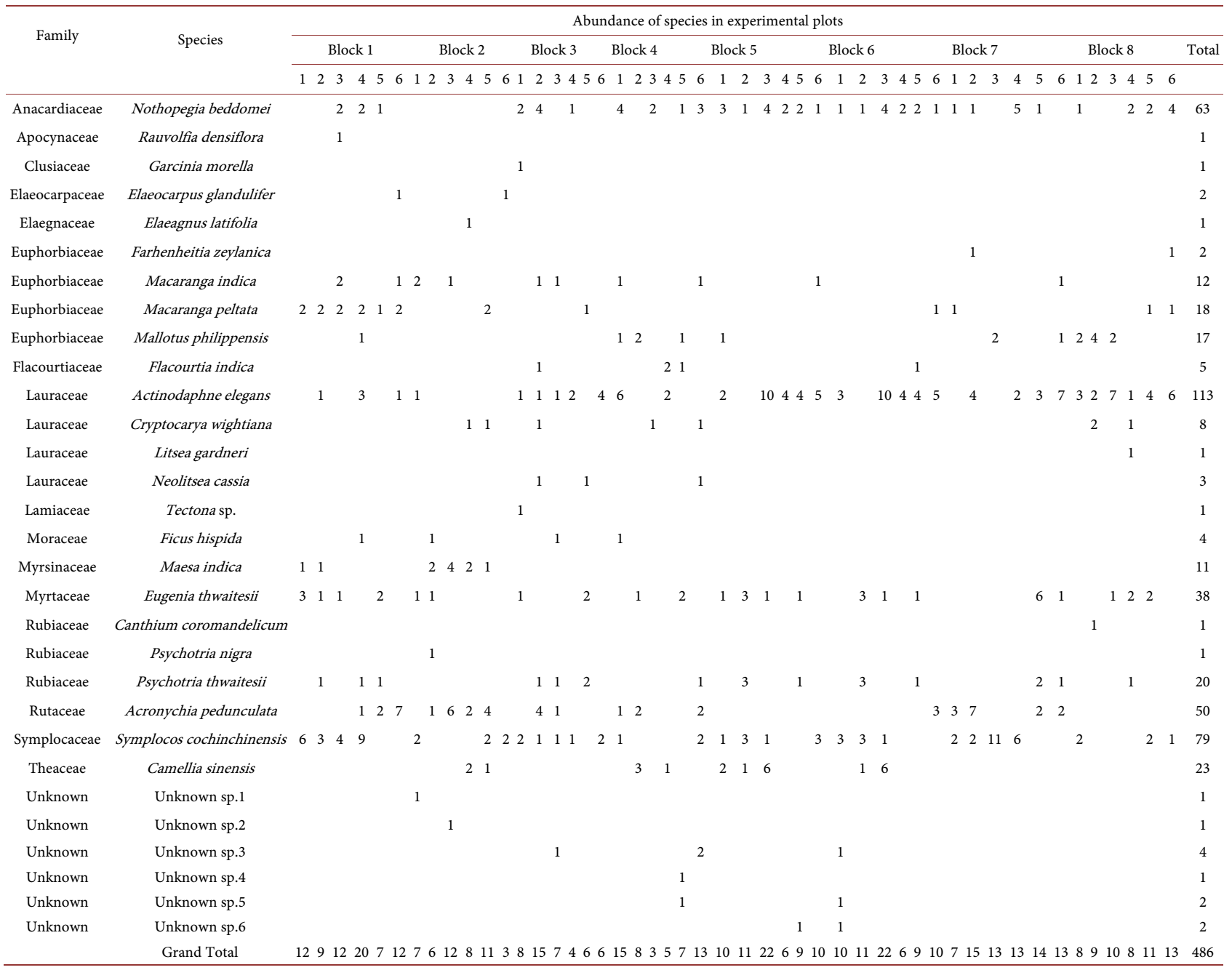

Table A4. Abundance of overstorey species recorded in the experimental plots in natural forest.

\begin{tabular}{|c|c|c|c|c|c|c|c|c|c|c|}
\hline \multirow{2}{*}{ Family } & \multirow{2}{*}{ Species } & \multicolumn{8}{|c|}{ Abundance of individual species in plots } & \multirow{2}{*}{ Total } \\
\hline & & 1 & 2 & 3 & 4 & 5 & 6 & 7 & 8 & \\
\hline Anacardiaceae & Nothopegia beddomei & 8 & & & & & 8 & 2 & 1 & 19 \\
\hline Clusiaceae & Calophyllum trapezifolium & 6 & 10 & 3 & 2 & 3 & 8 & 10 & 14 & 56 \\
\hline Lauraceae & Actinodaphne elegans & 5 & 6 & & 4 & & 11 & 13 & 5 & 44 \\
\hline Lauraceae & Litsea gardneri & & 1 & & & & & & & 1 \\
\hline Myrtaceae & Eugenia sp. & & & & 1 & & & & 2 & 3 \\
\hline Rubiaceae & Psychotria nigra & & & 7 & 4 & 7 & & & & 18 \\
\hline Symplocaceae & Symplocos cochinchinensis & & 7 & & 5 & & 4 & 4 & 2 & 22 \\
\hline Unknown & Unknown sp.1 & & 1 & & & & & & & 1 \\
\hline Unknown & Unknown sp.2 & & & 1 & & 1 & & & & 2 \\
\hline Unknown & Unknown sp.3 & & & 2 & & 2 & & 1 & & 5 \\
\hline \multirow[t]{2}{*}{ Unknown } & Unknown sp.4 & & & & 1 & & & & & 1 \\
\hline & Grand Total & 19 & 25 & 13 & 17 & 13 & 31 & 30 & 24 & 172 \\
\hline
\end{tabular}


Submit or recommend next manuscript to SCIRP and we will provide best service for you:

Accepting pre-submission inquiries through Email, Facebook, LinkedIn, Twitter, etc. A wide selection of journals (inclusive of 9 subjects, more than 200 journals)

Providing 24-hour high-quality service

User-friendly online submission system

Fair and swift peer-review system

Efficient typesetting and proofreading procedure

Display of the result of downloads and visits, as well as the number of cited articles Maximum dissemination of your research work

Submit your manuscript at: http://papersubmission.scirp.org/

Or contact ojf@scirp.org 